\title{
Toward a concept of pluralistic, inter-relational semiosis
}

\author{
Floyd Merrell \\ Department of Foreign Languages and Literature \\ Purdue University, West Lafayette, IN, USA \\ e-mail: fmerrell@purdue.edu
}

\begin{abstract}
Brief consideration of (1) Peirce's 'logic of vagueness', (2) his categories, and (3) the concepts of overdetermination and underdetermination, vagueness and generality, and inconsistency and incompleteness, along with (4) the abrogation of classical Aristotelian principles of logic, bear out the complexity of all relatively rich sign systems. Given this complexity, there is semiotic indeterminacy, which suggests sign limitations, and at the same time it promises semiotic freedom, giving rise to sign proliferation the yield of which is pluralistic, inter-relational semiosis. This proliferation of signs owes its perpetual flowing change in time to the inapplicability of classical logical principles, namely Non-Contradiction and Excluded-Middle, with respect to elements of vagueness and generality in all signs. Hempel's 'Inductivity Paradox' and Goodman's 'New Riddle of Induction' bear out the limitation and freedom of sign making and sign taking. A concrete cultural example, the Spaniards' world including the Virgin of Guadalupe and the Aztecs world including their Goddess, Tonantzín, are given a Hempel-Goodman interpretation to reveal the ambiguous, vague, and complex nature of intercultural sign systems, further suggesting pluralism. In fact, when taking the 'limitative theorems' of Gödel, Turing, and Chaitin into account, pluralism becomes undeniable, in view of the inconsistency-incompleteness of complex systems. A model for embracing and coping with pluralism suggests itself in the form of contextualized novelty seeking relativism. This form of pluralism takes overdetermination, largely characteristic of Peirce's Firstness, and underdetermination largely characteristic of Peirce's Thirdness, into its embrace to reveal a global context capable of elucidating local contexts the collection of which is considerably less than that global view. The entirety of this global context is impossible to encompass, given our inevitable finitude and fallibilism. Yet, we usually manage to cope with processual pluralism, within the play of semiosis.
\end{abstract}




\section{Contents}

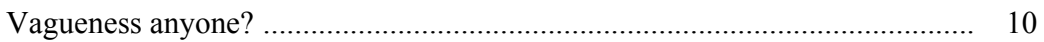

Playing one side against the other ............................................................ 14

Our signs' elusiveness ............................................................................. 18

Filling in a few more gaps ................................................................ 21

The categories, and the sign: toward the pluralist concept ............................... 23

What, in the final analysis, happened to classical logical principles? .............. 26

Hempel's 'Inductivity Paradox': substantive or existential anxiety ........ 27

Goodman's 'New Riddle of Induction': qualifying the anxiety ............... 28

Alien culture anxiety .................................................................................. $\quad 30$

Logical principles, and conundrums of deductivity ............................... 33

The problem complexifies even further: toward radical pluralism ........... 34

And yet, ... and yet, ... should we really fret over it? .................................... 35

Fret over it or not, this is our condition ...................................................... 38

When the semiotic gusher is at its best, what are the consequences? ............... 41

Yet, syncretic relativism has its attraction ............................................... 45

Some variations on the theme ................................................................. 48

Comes another counterargument ................................................................. 51

Others, and their cultural contexts ……….................................................. 54

Yet, is it not possible to understand others? .................................................. 56

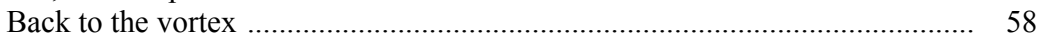

In other words, practice moderation in all things .................................. $\quad 62$

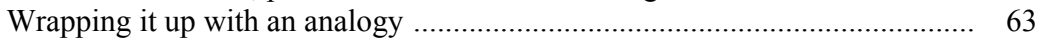

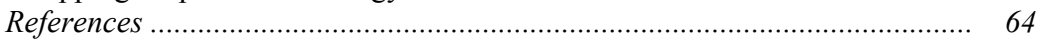

Abstract in Russian ............................................................................. 68

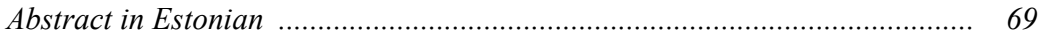

\section{Vagueness anyone?}

Charles S. Peirce occasionally alluded to what he labeled 'logic of vagueness' as 'logic' in 'the broadest possible sense'. Obviously, such 'logic' would go against the grain of classical bivalent logic insofar as it was developed in Peirce's time in part by Peirce himself, as well as by Boole, de Morgan, Whatley, Schröder, and others. One might expect that such a 'logic of vagueness' would follow the lines of 'triadic logic'. But it must be more than that. As 'logic' in 'the broadest possible sense', it should offer a foreshadowing of today's 'fuzzy logic' and 'paraconsistent logic'. ${ }^{1}$ Although Peirce never made good

'Fuzzy logic' has at least two chief sources over the past century. The first was initiated by Peirce during his occasional ruminations on a 'logic of 
on his promise to construct this general 'logic', in 1908 he did envision a 'triadic logic' based on 'real possibility', 'actuality', and 'real necessity', in line with his categories, Firstness, Secondness, and Thirdness. I turn to Peirce's effort along these lines as the preliminary stage in outlining a concept of pluralistic, inter-relational semiosis.

Peirce points out that a proposition asserting actual existents (Seconds) lies at the half-way house between the poles of assertion of possibility (Firstness) and those of necessity (Thirdness). ${ }^{2}$ While assertions regarding existents or 'actuals' follow the tenets of classical logic, assertions of possibility and necessity do not, not necessarily, that is. In Peirce's words:

that which characterizes and defines an assertion of Possibility is its emancipation from the Principle of Contradiction, [...] while that which characterizes and defines an assertion of Necessity is that it [...] throws off the yoke of the Principle of Excluded Third; and what characterizes and defines an assertion of Actuality, or simple Existence, is that it acknowledges allegiance to both formulae, and is thus just midway between the two rational 'Modals', as the modified forms are called by all the old logicians. (MS 678: 34-35)

What lies within the sphere of possibility (Firstness) by and large violates the Principle of Non-Contradiction, the principle that customarily reigns in the 'semiotically real' world of Secondness and classical logic. Within the sphere of Firstness, contradictories can quite comfortably exist side by side, for, given the nature of unactualized Firstness as a superposed set of possibilities, everything is there, timelessly. The sphere of Firstness composes an unimaginably massive, continuous collage of compatible and incompatible, consistent

vagueness'. Peirce's concept of vagueness later became the focus of studies by Brock (1979), Chiasson (2000), Engel-Tiercelin (1992), Merrell (1995, 2003), and Nadin $(1982,1983)$, among others. The second source is an outgrowth of work with 'fuzzy sets' in the 1960s and 1970s by Lofti Zadeh $(1965,1975)$. Regarding 'paraconsistent logic', which plays havoc with the classical Principles of NonContradiction and Excluded-Middle, see early work by Newton da Costa (1974), and later, especially Graham Priest $(1989,1991,1998)$ and Carnielli, Coniglio and D'Ottaviano (2002).

2 According to Peirce, any conceptual body of knowledge, no matter how complex, can be reduced to triadicity (three 'categories'), but triadicity cannot be further reduced. Although limited time and space do not permit my expounding on the categories in this essay, I would recommend Almeder (1980) and Hookway (1985). 
and inconsistent, and complementary and contradictory, nonessences. It is pure chance, spontaneity, infinitely diluted vagueness. Nothing is (yet) specified, and everything is virtually at one with everything else. There are as yet no distinctions, no borders, and no taxonomies. There is no static plenum, per se, but rather, effervescent, fluctuating, flickering, superposed possibilia in expectancy of their actualization into Secondness. Thus vagueness is thoroughly overdetermined. There is no knowing whether what would otherwise be considered two or more contradictory terms might not be considered equally 'true' at different times and places (e.g. the 'Earth' as center of the universe before Copernicus, the 'Sun' as center of the universe after Copernicus, and, after Einstein, neither the 'Earth' nor the 'Sun' is center but, so to speak, every place is its own center). ${ }^{3}$

The sphere of probability or necessity (Thirdness) includes mediation of terms, and mediation of mediations, with no end in sight. Thus, any and all sets of signs remain invariably incomplete; something more can always be added. Hence, unlike the crisp eithers and ors of Secondness, within Thirdness, the Excluded-Middle Principle threatens to fall by the wayside. Among any given set of signs, with sufficient time and changes of context, the potential always exists for other signs and their meanings, or the same signs and other meanings, to emerge and gain favorable recognition. It is not a matter of the 'center' of the universe either as the Earth (Ptolemy) or the Sun (Copernicus), but now, it is neither the one nor the other, but something else that may be in the process of emerging. In other words, the 'center' for Ptolemy and the 'center' for Copernicus is not simply a matter of either-or alternatives: with the demise of classical physics, the 'center' can now conveniently be conceived as something else altogether (i.e. something entered the gap between the erstwhile either/or categories to render them neither-nor). Consequently, given sufficient time, any and all conceptual schemes are destined to incompleteness, since no matter how replete the previously considered gap between the either and the or is filled, there will always be room

3 It will become evident that in this context I do not use overdetermination in the Freudian sense. It is not a compulsory drive to force all possible signs toward some predetermined end, but rather, an undetermined number of possible paths are always available to the range of possible signs; hence overdetermination offers an indefinite multiplicity of consequences for an indefinite set of sign possibilities. 
for something else. Due to this persistence of incompleteness, underdetermination necessarily prevails.

Overdetermination, in contrast to underdetermination, includes the domain within which a sign is not yet definitely or authoritatively decided, settled, or fixed - though according to the circumstances it presumably can be - and as such it is not bound by definite limits or restrictions.

Overdetermination is basically related to Firstness, as well as to the concepts of vagueness and inconsistency. However, overdetermination, in the purest sense, is actually tantamount to what we might label 'pre-Firstness', before there is or can be consciousness of a sign (Baer 1988). Consciousness of a sign, during the very moment it is emerging, remains vague, to be sure. As consciousness of the sign becomes more pronounced, and vagueness gives way to increasing precision, a small number of the indeterminate range of possible specifications of the sign can become actualized as Seconds to take their place in what is perceived and conceived to be the 'semiotically real' world usually interpreted in terms of either/or categories. But whatever specification might have been actualized, others remain as possibilities, some of them contradictory with respect to that which was actualized. In other words, regarding the Secondness and Thirdness of signs of which there is consciousness, and regarding which specification of meaning can be made more precise, underdetermination (qualified by generality and incompleteness) stands a chance of making its presence known here and there.

In another way of putting it, within the sphere of overdetermination, mutually incompatible possibilities of meaning can cohabit without undue conflict (and as a result, the Principle of Non-Contradiction loses some of its sting); within the sphere of underdetermination, actualized meanings within one timespace context can become something slightly to radically different within another timespace context (hence the Excluded-Middle Principle does not strictly apply). 


\section{Playing one side against the other}

The sphere of vagueness (of possibilia, Firstness) is timeless, while that of generality (actuals developing toward the fullness of Thirdness) is time-bound. By the very nature of this interrelationship, signs of generality are destined to suffer a fate complementary with that of signs of vagueness.

In this spirit, Peirce wrote that "[n]otwithstanding their contrariety, generality and vagueness are, from a formal point of view, seen to be on a par" (CP: 5.447). Vague signs cannot be construed as vague unless endowed with at least a tinge of generality, and general signs, given their inevitable degree of incompleteness, are invariably somewhat vague. Peirce readily conceded that no sign can be equally vague and general from the same perspective and from within the same timespace context, since insofar as the determination of a sign is extended to the interpreter - i.e. the case of generality - it is by and large denied to the utterer, and insofar as it is extended to the utterer i.e. the case of vagueness - it lies largely beyond the grasp of the interpreter (CP: 1.463-69, 5.447-57). By no means, however, do I wish to imply that Firstness has a monopoly on vagueness, but rather, vagueness to a greater or lesser degree pervades any and all signs.

It bears mentioning that the interrelationships herein implied between vagueness and generality — and overdetermination and underdetermination - are not customarily forthcoming in philosophical discourse. To cite certain notable exceptions, Bertrand Russell (1923) relates the law of excluded-middles exclusively to vagueness. Willard V. O. Quine $(1953,1960)$ focuses almost obsessively on underdetermination with respect to scientific theories, and by extension, natural language. More recently, Donald Davidson (1984) throws vagueness into the same bag with generality and incompleteness without showing how they are agonistically set apart and at the same time intricately intertwined.

That much said, the inevitable vagueness and generality of all signs, however small, suggests that every sign is at least partially determined, and its partial determination is contingent upon its varying degree of context-dependent vagueness and generality:

A sign (under which designation I place every kind of thought, and not alone external signs), that is in any respect objectively indeterminate (i.e. whose object is undetermined by the sign itself) is objectively general in so far as it 
extends to the interpreter the privilege of carrying its determination further. Example: 'Man is mortal'. To the question, What man? the reply is that the proposition explicitly leaves it to you to apply its assertion to what man or men you will. A sign that is objectively indeterminate in any respect is objectively vague in so far as it reserves further determination to be made in some other conceivable signs, or at least does not appoint the interpreter as its deputy in this office. Example: 'A man whom I could mention seems to be a little conceited'. The suggestion here is that the man in view is the person addressed, but the utterer does not authorize such an interpretation or any other application of what she says. She can still say if she likes, that she does not mean the person addressed. Every utterance naturally leaves the right of further exposition in the utterer, and therefore, in so far as a sign is indeterminate, it is vague, unless it is expressly or by a well understood convention rendered general. (CP: 5.447; also 1.434)

Thus, "a sign can only escape from being either vague or general by not being indeterminate". Yet no sign "can be absolutely and completely indeterminate" (vague) (CP: 5.506). For a sign, "however determinate, may be made more determinate still, but not [...] absolutely determinate" (general) $(C P: 3.93)$. This is to say that if a sign were totally determinate, it would always be as it is, its attributes remaining intact and changeless. And if a sign were totally indeterminate, it could not have become an actual sign (of Secondness) for some interpreter in some sense or other.

In everyday situations, when the plethora of potentially variant timespace contexts comes into the picture, the possibility of any absolutely determinate sign dissolves. There was President Bill Clinton as now neoliberal, now for social programs, now wooing the conservatives, now catering to the business community, now also of the working class and capable of eating hamburgers and French fries with the best of them, now favorable to the educators, now sympathetic with women and minority groups and gays, now friendly with the women folks but doing nothing improper, now intimate with members of the opposite sex but still morally upstanding, and these days, Bill Clinton is ex-president and knowledgeable observer of the global scene and campaigner for his wife's presidential nomination. Bill Clinton, like all signs, can be many things to many people. Like all signs, he simply cannot stand still. Were a changeless sign actually to exist, it would be autonomous, individual, and indivisible. However, such absolutes "can not only not be realized in sense or thought, but cannot exist, properly speaking. For whatever lasts for any time, 
however short, is capable of logical division, because in that time it will undergo some change in its relations" $(C P: 3.39 n 1)$.

So, every sign must relate to some not-quite-absolutely-general 'semiotic object'. ${ }^{4}$ The 'object' cannot be the absolutely 'real object' as it is, for all 'objects' are related to all other 'objects' of a given field of signs. To be sure, all signs relate to some singular 'object', at least potentially understood by all semiotic agents. But since the 'really real' in all its plenitude lies perpetually beyond our grasp, there must exist some lesser sphere containing signs and their 'semiotic objects'. That sphere is partly shared by the semiotic agents involved in dialogic exchange, and those signs and semiotic 'objects' are to a greater or lesser degree general, though never absolutely so, and hence they are to a greater or lesser degree vague. Vagueness and generality are in this sense complementary forms of semiotic indeterminacy. A sentence can be determinately judged either 'true' or 'false' in a given 'here-now', though in the 'there-then' its value might have suffered a change - in this manner Peirce's conception of 'logic' in the 'broadest possible sense' embraces temporality. And a sentence that has been determined either 'true' or 'false' in one respect may be neither 'true' nor 'false' in another. A sound can be neither blue nor red in the literal sense, though it may conceivably be either the one or the other in the synaesthetic sense. Consequently, the predicates 'shrill' or 'mellow', 'bitter' or 'sweet', or 'blue' or 'red' attached to the sign can be both 'true' and 'false' from within the range of all possible conceptions.

Vagueness, given its nature as indefinite, ambiguous, and indeterminate, takes the terms 'possibility', 'chance', 'spontaneity', and 'novelty' into its embrace. Generality includes the Peircean terms 'potentiality', 'convention', 'necessity', 'conditionality', and 'regularity' - all of the category of Thirdness - which imply process, growth, intellect, and mind (CP: 1.340). Generality thus calls for ever greater account of particular signs and their attributes as types. Yet, to expect absolute determinacy through generality is out of the question: there can be no more than an approximation toward a sign's meaning

4 Peirce uses the term 'object', and I attach to it the term 'semiotic', to distinguish it from the 'independently real' object in the physical world. Actually, elsewhere I have used a tripartite set of terms, 'object', 'act', and/or 'event', all of which can qualify as signs, the latter two terms themselves interrelating with one or more 'semiotic objects' (Merrell 1997, 2000, 2003). 
in its most general sense. ${ }^{5}$ While generality entails relations to semiotic 'objects', vagueness bears no form or fashion of relatedness of signs to other signs established by some semiotic agent. Pure vagueness (Firstness) is the superposition of all possibilities without any of them (yet) being actualized. However, vagueness of actual signs (Secondness) requires their concrete contextualization and their being related to other signs. Such actualized signs, according to their interpretation, can now take on generality (Thirdness). It is for this reason that further determination of a general sign is left to the conceptual scheme, the criteria, and the style of reason and the wishes and whims of its interpreter. In contrast, determination of a vague sign depends upon further revelation and specification of its meaning by its author and the context of its engenderment.

In view of the complementarity of vagueness and generality, in a finite community of fallible semiotic agents, there can be no unadulterated sign of generality without at least a tinge of vagueness. And there can be no purely vague sign, for once actualized in order that it be made intelligible; a vague sign must take on at least some modicum of generality according to its interpreters' inevitable beliefs, habits, presuppositions, prejudices, and preconceptions. If any form or fashion of a 'logic in the broadest possible sense' there may be, it must include the spheres of both vagueness and generality. The upshot is that insofar as we, semiotic agents, are concerned, all generals are also possibly false at some time and place or another (i.e. the incompleteness of underdetermination), therefore they can be taken only conditionally as necessary, those conditions always remaining subject to their partial fulfillment, or in the event that they are false, to their unfulfillment.

Now for a further look at the complementary role of a sign's author and its interpreters - themselves also signs.

5 The allusion here is to Peirce's often maligned idea that science - and knowledge in general - is in a process asymptotically of approximating the truth (for a critique of Peirce's convergence theory, see Rorty 1991; for a discussion of the pros and cons, Skagestad 1981; for a defense, Hausman 1993). 


\section{Our signs' elusiveness}

Taking into account the composite characteristics of possibility (Firstness), actuality (Secondness), and potentiality (Thirdness), what I have summarily alluded as a Principle of Indeterminacy is crucial to an understanding of Peirce's notion of semiosis.

Quite obviously, Peirce was keen on the idea that we dwell in a vague and inconsistent, and general but perpetually incomplete, world of signs. The ubiquity of vagueness and inconsistency breeds a tendency to embrace contradiction and paradox. And the inevitability of incompleteness in all signs of general nature allows for the entrance of unexpected thirds without conceivable end. Yet, Peirce writes in so many ways that the collusion of possibility, actuality, and potentiality makes up our 'semiotically real world' as we perceive and conceive it, which, if we are fortunate, stands a chance of approximating some portion of the 'real'. Any and all 'semiotic worlds', in this light, must remain radically uncertain, for, "when we busy ourselves to find the answer to a question, we are going upon the hope that there is an answer, which can be called the answer, that is, the final answer. It may be that there is none." ( $C P: 4.61)$

To be more specific, Peirce does not use the pair of Kurt Gödel terms, inconsistency and incompleteness, now commonplace in mathematics, logic, and physics (Nagel, Newman 1958; Goldstein 2005). However, his vagueness-generality dyad is brought in line with something reminiscent of a Gödelian framework by Nicholas Rescher and Robert Brandom (1979: 124-26), though admittedly for a different purpose (see also Merrell 1995; Nadin 1982, 1983). The relationship between vagueness-generality and inconsistency-incompleteness and their relevance to indeterminacy (or undecidability) becomes apparent if one sufficiently contemplates Peirce's suggestion, as cited above, that "[e]very utterance naturally leaves the right of further exposition in the utterer; and therefore, in so far as a sign is indeterminate, it is vague, unless it is expressly or by a well-understood convention rendered general". In other words, the indeterminately vague sign calls out to its maker for further clarification, since that which can render it less vague is more accessible to the possibilities that lie before her than before the sign interpreter.

If a sign of vagueness includes contradictions, then the sign's meaning for one community might be incompatible with its meaning 
for another community at the same or another time, or that same community at another time. And if a sign of generality is never determined to the extent that it cannot be determined further, then an unordered set of potential interpretations exists with the characteristic that between any given pair of alternate interpretations there can always be a third one. In other words, as we have noted, the ExcludedMiddle Principle loses part of its sting. A small group of mathematicians, the intuitionists, deny the Excluded-Middle Principle altogether. They would discard statements like "Either there is a string of 18 consecutive $5 \mathrm{~s}$ somewhere in the decimal expansion of $\pi$ or there is not", since they can most likely enjoy no proof in our finite world. That is to say, 'truth' is intimately linked to provability. For quite different reasons, a handful of quantum theorists also reject the Excluded-Middle. In fact, John von Neumann pioneered an alternate 'logic', 'quantum logic', especially tailored to the needs of quantum phenomena. Following the general implications of quantum theory and quantum logic, a sign's becoming a genuine sign depends upon the interpreter's interaction with it. Just as no 'wave packet' is an actualized 'particle-event' until it enters into relationship with some aspect of its surroundings, so also no sign is a full-blown sign until it has been actualized (and interpreted) by some interpreter in some respect or capacity (Fraassen 1974; Heelan 1974).

An additional example may serve to illustrate the idea that: (1) a sign is not a genuine sign until it has interacted with some semiotic agent, (2) within the (vague) realm of all possible signs, inconsistency or contradiction inevitably prevails, and (3) given the range of all (general) signs, past, present, and future, there is no guarantee that the Excluded-Middle applies, hence the meaning of any and all signs will be incomplete. For example, assuming I have little knowledge regarding a particular event reported in the newspaper, I can read each individual sentence with rather wide-eyed, innocent - and exceedingly vague - belief. Yet at a more general level I may also believe that this article, like all others, is in all probability the victim of at least some degree of biased reporting. I tend to believe each individual sentence as it stands, but at the same time I am willing to concede to the possibility that my belief in a given sentence can embrace contradiction, since I also believe that, lurking somewhere in the report, there is undoubtedly some distortion of the 'truth'. So I take the article as a whole with a grain of disbelief, though I have not 
yet encountered any sign of deceit: it remains as a sign of possibility. Even though I might not have been able to catch the reporter at her devious game, I may still retain my faith that a closer reading will in all likelihood reveal some sort of inconsistency (i.e. that the sign of possibility will be actualized). In other words, I believe the article is neither wholly 'true' nor wholly 'false', but somewhere in between (we once again realize that banishing any and all contradictions and paradoxes is an interminable and hence futile enterprise). Extrapolating from Peirce, it follows that, as has been summarily intimated above: (1) an assertion of possibility (Firstness), having found newborn freedom from the Principle of Noncontradiction, rests chiefly within the domain of vagueness; (2) an assertion of necessity (Thirdness), liberated from the fetters of the Excluded-Middle Principle, pertains primarily to generality; and (3) an assertion of actuality (Secondness) by and large, and for practical purposes, remains by and large obedient to the demands of classical logic.

This collusion of vagueness and generality constitutes a fundamental principle of what Peirce envisioned for his 'logic in the broadest possible sense'. According to the tenets of classical logic, once the identity of a proposition has been determined, it is either 'true' or 'false'. But for Peirce's more general 'logic', as long as a proposition remains indeterminate - which must always be the case to a greater or lesser degree — it is not necessarily 'true' that it is either 'true' or 'false'. In fact, it may also be neither 'true' nor 'false', for some newly born 'truth' may exist somewhere between the erstwhile horns of the presumed extremes of 'truth' and 'falsity'. And until the proposition is an absolutely determinate actuality — which will never be the case in a finite setting of fallible semiotic agents - it may be 'true', given its vast range of all possible determinations at diverse timespace contexts, that it is both 'true' and 'false'. Peirce's 'logic', it tentatively appears, reflects a tension and potential mediation between vagueness and generality, the individual and the universal, and discontinuity and continuity. This accounts for the elusiveness of his hopeful 'logic', and his obvious difficulty in bringing it to fruition. ${ }^{6}$

\footnotetext{
6 Peirce's 'logic' also endows the terms in question with a flavor somewhat reminiscent of Niels Bohr's complementarity regarding the wave/particle duality, of Werner Heisenberg's uncertainty, which, he argued repeatedly, is more a
} 


\section{Filling in a few more gaps}

The underdeterminationist assumption has it that, intuitively, we believe something but not everything is 'real'. Since we cannot by empirical means discover what is 'real' without a shadow of a doubt, the matter is left to our judgment, according to our persuasions and propensities and wishes and whims. Underdetermination implies that what is taken as 'real' could always have been construed otherwise, and what is 'unreal' may yet stand some outside chance of becoming 'real' at another time and another place. Underdetermination regarding scientific theories also stipulates that competing and equally legitimate theories - equally legitimate from within their particular conceptual schemes, that is can be generated on the basis of the same set of observations. ${ }^{7}$

Quine (1969) argues that a theoretical sentence in physics can have the same underdetermined relation to experiments and observation sentences that a sentence of natural language has to the observed objects, acts, and events that it is about (Vuillemin 1986). He writes that since experience is never an infallible adjudicator for rejecting or embracing individual theoretical sentences, theoretical physics cannot be other than an interconnected web of sentences, procedures, and formalisms in contact with the world only at its edges, if at all. Any impact observation sentences may have on the web becomes distributed throughout the web such that no part of it is immune to change, and no part stands alone in bearing the brunt of that impact. Additions, deletions, and adjustments of diverse sorts can often be made in the whole to accommodate the experience, but there is no infallible or unique method for making these adjustments. Four naturally occurring elements or many of them, phlogiston or oxygen, Euclidean geometry or Reimannian or Lobachevskyan geometry,

methodological and epistemological than an ontological necessity, and of Gödel's incompleteness-inconsistency (Merrell 2000).

7 In this vein, at the turn of the century, Pierre Duhem (1954) and Henri Poincaré (1958), and more recently, Nancy Cartwright (1983) and Hilary Putnam (1983), argue that there will always be equally satisfactory alternatives to a given theory or general theoretical framework. Consequently, no single story can account for all the furniture of the world in one fell-swoop. This is, in essence, the Duhem-Quine scenario - in which Peirce is a principle actor, though his role in this respect is often overlooked - predicated on the radical underdetermination of theories (i.e. they are empirically equivalent but logically incompatible) (see also Gähde and Stegmüller 1986, Roth 1987, Sacks 1989). 
Darwinian or Lamarckian evolution, all during certain periods, have been aided and abetted by proper 'empirical' or at least 'intuitive evidence' from one perspective or another. According to the dictates of a community's desires, what now appear to us as the most bizarre of theories could be, and at times have been, granted 'truth value'. And when fads, fashions, and tastes have suffered from the introduction of alternatives, theories have either followed suit, or they have served as stimuli for the most likely candidates from among those alternatives.

Given the nature of underdetermination, it is often possible to embrace logically incompatible but empirically equivalent theories albeit at different times and in different places. As a consequence, competing and mutually exclusive theories may always be available to account for the observational data at hand. Arguments for determining absolute 'Truth' are thus rejected: we can at best only know what we (think we) know, for we can't know whether what we know is infallibly 'true'. That is, by Peircean refutation or Popperian (1963) falsification, we can't know that what we know is not 'false'. So the dominoes are set up only to be knocked down. Yet the hope persists that to all questions an answer can eventually be found; otherwise there would hardly be any motivation for continuing to play the game of inquiry. In other words, thought can potentially cure all ills, though when put into signs for communication with other semiotic agents, it often threatens to become undecidable.

It would appear that our ideals are perpetually out of line with our real capacities. Such is the general nature of Peirce's doctrine of fallibilism. Thus we see with greater force that overdetermination and underdetermination apply to the very idea of fictionality, and especially to the inexorable fuzziness between fictions and the 'semiotically real'. The exact quantity of gold in Pike's peak, the cause of Hamlet's dementia, Napoleon's reason for his decision at the Battle of Waterloo, Don Quixote's height, the use of $\sqrt{ }-1$ in quantum theoretical equations, the absolutely precise nature of the sun with respect to all other entities in the firmament, are all underdetermined in that they are never so complete as to be immune to further determination. Consequently, a community's fabric of signs is read into experience, and in the process it becomes the world that is, the 'semiotically real'. 'Semiotically real' signs from diverse time periods and from a variety of belief that are pregnant with meaning ('mass', 'energy', 'Eucha- 
rist', 'Big Foot', 'Zeus', 'UFOs', 'mana', 'witches', 'AIDS', 'cholesterol', and the 'Cross' and 'Swastika') have become excessively impregnated because of the role they play and the place they occupy in their respective interwoven semiosic fabric. They do not describe experience; they are 'intersubjective idealizations', whether dressed in relatively concise and complete abstract language or in everyday language and enshrouded in vagueness, thus much of their meaning remains implicit.

After all has been said and done, the overdetermination (vagueness) - underdetermination (incompleteness) pair of terms is itself perhaps most economically viewed as two complementary approaches toward knowing what is (see especially $C P$ : 2.322-23). The two approaches pattern the Heraclitus-Parmenides and Aristotle-Plato antagonisms. In their purest form, one is messy and unkempt; the other is orderly. One is rich in the variety of its concrete particulars; the other is formal and parsimonious. The one is a maze of tropical flora; the other is a barren desert converted into a grid of meticulously cultivated plots. But there must be more: the Included-Middle emerging from within the pairs of terms, evincing inconsistencies here and there, keeping the complementarities together, in spite of whatever tensions might arise. So, we cope with our unruly signs, as best we can, and get on with life's processes. This is to suggest that semiosis, which is continuous process rather than finished, relatively fixed product, cannot but be construed as the possibility for pluralist semiotics.

Let us now take up Peirce's categories insofar as they bear on his concept of the sign.

\section{The categories, and the sign: toward the pluralist concept}

To recap, Firstness is possibility, what might become; Secondness is actuality, what has become or presumably is; and Thirdness is the likelihood or probability that what has become is in the process of becoming something other than what it was becoming due to the prevailing conditions. Metaphorically speaking, Firstness is position, stasis; Secondness is velocity, change; Thirdness is acceleration, change of change.

Figure 1 gives us an impression of Thirdness as mediating Firstness and Secondness and bringing them interdependently, inter- 


\section{Floyd Merrell}

relatedly and interactively together in the same way that it comes into interdependent, interrelated interaction with each of them (the italicized terms - hereafter specified as $i-i-i-$ — are not Peircean in origin; nevertheless I believe the way I use them in this essay is in the spirit of Peirce [see Merrell 2000, 2003, 2004]). I use a 'tripodic' model of the 'processual' interrelationship between the categories: 'processual' because the lines of interconnection are always flowing and becoming something other than what they were becoming.

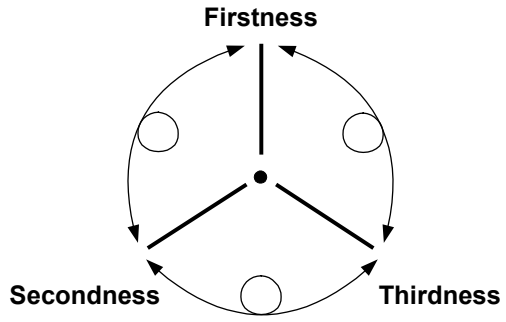

Figure 1. Thirdness as mediating Firstness and Secondness and bringing them interdependently, interrelatedly and interactively together, coming thus into interdependent, interrelated interaction with each of them.

This semiosic flow also qualifies Peirce's sign components, which are most adequately presented in tripodic form (see Fig. 2). Since the interpretant brings the representamen and semiotic object into $i-i-i$ - in the same way it comes into $i-i-i$ - with them, the tripod is in a manner of speaking 'democratic'. All three legs are necessary. Remove any one of them and the tripod falls. The representamen and semiotic object without an interpretant are disconnected; the interpretant without a representamen and a semiotic object is of no consequence.

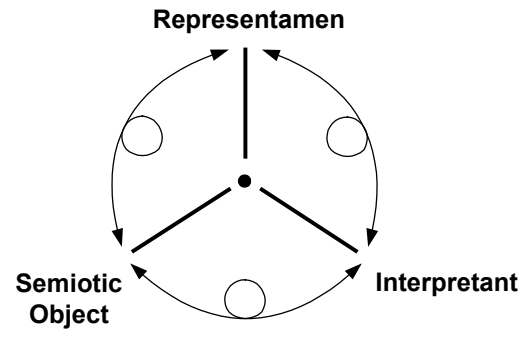

Figure 2. Peirce's sign components in tripodic form. 
A disconnected representamen, as Firstness, is no more than an 'autonomous atom'. Unless it interrelates with something other than what it is - some 'semiotic object' - it cannot become a genuine sign. A 'semiotic object', or Secondness, without the Firstness of the sign, also simply is what it is, and no more. In other words, a semiotic 'object' of Secondness cannot become a genuine sign without a representamen with which it can interrelate. Thirdness plays the role of bringing the representamen and semiotic object, Firstness and Secondness, into $i-i-i-$, and at the same time it brings itself into $i-i-i$ with them. But neither can the interpretant, in and of itself, become a genuine sign.

This triadic process can be summarized as follows:

A. Firstness as representamen implies a set of possible instantiations of Secondness as 'semiotic objects' and their possible interpretants. A First can emerge within different timespace contexts. This is to say that within a given timespace context, a possibility can emerge in coherence with other possibilities, and within another timespace context, a contradictory possibility can emerge, but both the possibility and its contradictions cannot emerge within the same timespace context - this characteristic entails genuine complementary interrelations. Hence the classical logical Principle of Non-Contradiction does not hold within the overdetermined sphere of Firstness, or sign possibilities.

B. Secondness is a possibility that has emerged as a semiotic object in $i-i-i$ - with its respective representamen as Firstness. A Second entails what is taken as 'real', and as 'real', ordinarily it cannot be anything other than what it is. It is either what it is or it is not what it $i s$; but it $i s$ what it is taken to be, therefore it presumably cannot be anything else. Hence the classical Principles of Identity, NonContradiction, and Excluded-Middle usually apply to Secondness insofar as what is a Second is perceived and conceived according to the social conventions that are collectively accepted by the community of sign makers and takers.

C. Thirdness is the likelihood that a semiotic object will come into $i-i$ $i$ - with a given representamen according to some set of conventions. This is due to the mediary effective of an interpretant that brings about the emergence of meaning of the sign. The act of mediation occurs in time, which is to imply that successive timespace contexts come to bear on the process of $i-i-i$ - between 
Firstness, Secondness, and Thirdness, and representamen, 'semiotic object', and interpretant. Time, with respect to Thirdness, accompanies change, and change introduces unpredictability regarding future timespace contexts. Thus, whatever possibility of Firstness (a representamen) might have emerged to come into $i-i-i$ with some possibility of Secondness (a 'semiotic object') mediated by some possibility of Thirdness (an interpretant), at some later moment the conditions might have changed such that other alternate, and conceivably more viable possibilities can emerge, even though they may be incompatible with the possibility that preceded them. Consequently the classical Principle of Excluded-Middle does not necessarily apply within the underdetermined sphere of Thirdness.

How to cope with Peirce's apparently outlandish claims about the Principles of Non-Contradiction and Excluded-Middle? Perhaps by beginning with the question ...

\section{What, in the final analysis, happened to classical logical principles?}

A Peircean example of a general statement or proposition might be: (1) 'All swans are white'. It seems quite unproblematic, and to take it as neither true nor false would certainly seem counter-intuitive. An example of vagueness can be: (2) 'I could say something about George Bush'. What the speaker could say might be both one statement and another contrasting statement, and it might be interpreted in both one way and another way, depending on the interpreter.

Validation of (1) depends on the sign taker's past experience and potential future experience of the whiteness or nonwhiteness of all swans. In this event there exists the possibility, however remote, that it is neither the case that all swans are white nor that no swans are white, but rather most swans might be white with the exception of a few swans, that happen to be black. Determination of (2) depends on the sign maker's further specification of what she might say. If she says 'Bush is a moron', the statement could be taken as true by some sign takers and false by others. So it might be said that the as yet unactualized sign is still both true and false, given the timespace context of its interpretation. If it is taken as both true and false within the same 
timespace context it is nothing at all; in other words, it cannot be more than a possibility of either the one or the other of the two signs (for further on this topic, see Margolis 1991: 40-53, Lane 1999, Merrell 2007, and Peirce $C P: 5.447,1.434,2.598, M S 611,6.168$ ).

We have, then, at one pole, general signs of chiefly Thirdness that are not necessarily determinable by the Principle of ExcludedMiddles, and at the other pole, vague signs of chiefly Firstness that are not necessarily accountable to the Principle of Non-Contradiction. Where's the security in all this? By and large in the middle, where signs chiefly of Secondness play their key role. These signs, as we make and take them according to our habituated ways and our social conventions, lend themselves to either/or alternatives, hence when on their best of behavior they abide by Identity, Non-Contradiction, and Excluded-Middles. A sign saturated with vagueness entails the possibility of an interpretant; a sign in the most general sense is a sign whose interpretant can be up for reform or rejection; a sign of either/or alternatives is a sign taken in terms of its truth/false values, however tenuous those values may be.

It would seem that our signs, in their composite form, are more complex than we would perhaps wish to admit. This assumption cries out for a closer look.

\section{Hempel's 'Inductivity Paradox': substantive or existential anxiety}

Carl Hempel (1945) argues that sentences in the order of 'All swans are white' can be restated as 'All nonwhite things are nonswans'. How so? Actually, the two hypotheses have the same content; they are different formulations of the same proposition. In order to demonstrate this, Hempel posits what he calls the equivalence condition between the two hypotheses: whatever confirms (or refutes) one of the two equivalent sentences, also confirms (or refutes) the other.

In other words, one hypothesis is a contrapositive of the other hypothesis. To state 'That swan is white, therefore all swans must be white' also confirms the statement 'That bear is a nonswan and it is nonwhite, therefore all nonwhite things must be nonswans'. Of course 'All nonwhite things are nonswans' is the much easier of the two hypotheses to test. Pink flamingos, red cardinals, gray doves, yellow 
canaries, and blue jays, all confirm the contrapositive version of the hypothesis, as do yellow lemons, silver coins, red herrings, and green emeralds. So we can go through life, at each step spying either white swans or nonwhite nonswans, and our original hypothesis asserting that all swans are white will not yet be absolutely confirmed, for something will always remain to be observed, including species of insects in the Amazon basin becoming extinct daily. (And, true to form, Captain Cook once discovered some black swans while exploring Australia, thus confirming the statement 'Most swans are white, but some are black, namely a strain of swans that can be found down under'. So now we know, at least until somebody might happen to run onto a nonwhite-nonblack swan, somewhere and sometime.)

Here, then, we have a prime example of a general sign further specification of which depends on us, the sign takers. In spite of Hempel's 'inductivity paradox', we usually do what we do best, and get on with it. We send and take, and engender and translate signs, and we cut the world up as we go along. We compare new experiences to old ones, and pack signs into the pigeon-holes with which we have become comfortable, notwithstanding the risk we constantly run in view of the assumption that what is correct from one vantage may be absurd from another. However, during life's processes within that culture, every item of experience that happens to pop up might possibly bring us to an awareness of the underdetermination of our signs, and of the incompleteness of our semiotic world. Given Hempel's paradox regarding the inexorable incompleteness of our inductively derived generalities, how can we hope to avoid pluralism?

As if Hempel weren't enough, there's more to come.

\section{Goodman's 'New Riddle of Induction': qualifying the anxiety}

Goodman's (1965) 'New Riddle of Induction' goes like this. We would like to believe that the statement 'Emeralds are green' is beyond doubt true. Supposing that all the emeralds we have examined before a given time are 'Green', we are quite confident that 'Emeralds are green' will always be confirmed, for according to our observations, emerald $a$ on examination was 'Green', emerald $b$ was 'Green', and so on. 
But suppose we meet someone from Netherworld whose perception of things is out of sync with ours. Among other oddities, Netherworlder's language contains the following two terms which we, after a few hits and misses, learned to translate into our language thus:

Grue

$=$ examined before the temporal 'reference point' $t_{0}$ and is reported to be 'green' or is not examined before $t_{0}$ and reported to be 'blue'. $\left(t_{0}\right.$ is apparently an otherwise arbitrary moment of time that is not in the past.)

Bleen $=$ examined before the temporal 'reference point' $t_{0}$ and is reported to be 'blue' or not examined before $t_{0}$ and is reported to be 'green'.

Before time $\mathrm{t}_{\mathrm{o}}$ our statements assert an emerald is 'Green', but Netherworlder has a parallel statement asserting it is 'Grue'. And as far as she is concerned, her observations that emerald $a$ on examination is 'Grue', that emerald $b$ is 'Grue', and so on, adequately confirm her own hypothesis. It will obviously appear to us from the standpoint of our language and our color taxonomy that Netherworlder's sensory images change radically after $t_{0}$. But actually, from her perspective, the glove is turned inside out: as far as she can tell, it is our taxonomy that is time-dependent. That is, Netherworlder's translation of our color scheme would result in the following report:

Green $=$ examined before $t_{\mathrm{o}}$ and is reported to be 'grue', or not and is reported to be 'bleen'.

Blue $=$ examined before $t_{0}$ and is reported to be 'bleen', or is not and is reported to be 'grue'.

From the perspective of each translator, the other's inductive process is false. Apparently, there is no possible resonance with respect to 'Green' and 'Grue'. However, if the two perspectives are taken together as an atemporal whole, they are symmetrical; but when taken separately as self-sufficient wholes, they are asymmetrical with respect to one another (Gärdenfors 1994; Rescher 1978). In a manner of speaking, we and Netherworlder possess our own Jacques Derrida 'metaphysics of presence' with respect to other's conception of the 
world, though, from the other's complementary world, this 'metaphysics of presence' is easily demythified (Hesse 1969).

In short, Netherworld and Ourworld are two, and they are both consistent enough from within the purview of Netherworlders and Ourwordlers, respectively; yet they appear incompatible; and yet,... if we can at least partly understand Netherworld, and if Netherworlder can at least partly understand Ourworld, then the two worlds can't be entirely incommensurable. Both have been drawn from the sphere of all possible worlds: The World.

Hempel's paradox tells us that surprises are inevitable somewhere along the road. These surprises entail differences that make a difference, some of them earthshaking, revealing that our world is something other than we thought it was, and letting us know that virtually nothing is absolutely fixed. Goodman's dilemma tells us that different individuals from the same culture, and most strikingly, individuals from different cultures, can throw a monkey wrench in our conventions (presuppositions, predispositions, prejudices), such that we either ignore other ways of taking our world version and other world versions in general. The two problems suggest: (1) the inevitable complexity of our particular world version, here and now, when considered in view of all possible world versions, and (2) the inevitability of our confronting multiplicity during every step, whether we are talking about abstract ideas and concepts or walking along life's swerving, sinuous path.

Another score for pluralism. But enough imaginary constructs; let's return to real life situations within the concrete world.

\section{Alien culture anxiety}

We can't seem to break entirely free from imagination - we're always in some form or other in tune with that sphere of possible worlds, by way of Firstness. In this vein, the story I have in mind entails an imaginary construct in the most radical sense.

Bizarre though it might seem, my story, including the Patron Saint of Mexico, the Virgin of Guadalupe, exemplifies a combination of Hempel's paradox and Goodman's riddle. In 1531, ten years after the Aztec nation had been subdued by the Spaniards, the Virgin Mary purportedly appeared before Juan Diego — an Amerindian originally 
brought up in the tradition of the Indigenous people's own Virgin Goddess, Tonantzín. The Mexican Catholic Virgin eventually became known as 'Guadalupe'. The Catholic fathers appropriately distinguished between 'Guadalupe' and the Aztec goddess, 'Tonantzín', before $t_{0}$, and after $t_{0}$, such distinction remained in force. As far as the good fathers were concerned, Guadalupe was, and would always be, an exclusively Catholic image.

Such clarity and distinction, however, simply doesn't hold as far as human cultures go: they involve flowing, fluctuating $i-i-i$ - phenomena as described above. The Amerindians' cultural experiences serve to bear this out. The Amerindians' image presented a countenance of conformity to the Catholic tradition that usually pleased the Spaniards, for sure. But underneath this countenance, the Amerindians nurtured vestiges of their traditional beliefs, and thus resisted the Guadalupe image thrust upon them by the Spaniards. And how were their traditional beliefs manifested? By combining their cherished 'Tonantzín' with 'Guadalupe' — in paradoxical Goodmanesque fashion - to create the image of 'Guadantzín' (or 'Tonalupe', depending upon the emphasis), a transformed Aztec image in lieu of the Catholic image. That is to say, the two images, 'Guadalupe' and 'Tonantzín' were fused, confused, and hybridized, such that something new emerged from within the erstwhile Excluded-Middle. ${ }^{8}$

Now, since, pace Goodman's 'paradox', what is experienced as 'true' at one time may be experienced as 'false' at another time, given the perspective, we obviously need some provision in order to account for change and time. Time-dependent considerations of 'truth', of course, go against the grain of much modern logic. Peirce, however, believed logic to be a normative practice, and hence time-bound. How can we apply Peirce's vagueness to the concrete life situation involving conquerors and conquered in Mexico?

Let us consider concrete experience of the world's objects. At a particular point in time, experience of some of these objects can become ambiguous, or even anomalous: for instance, Ludwig Wittgenstein's (1953) allusion to the Rabbit/Duck' ambiguity. Suppose

\footnotetext{
8 Admittedly, I summarize this story to the extreme, which is necessary given the limitations of this essay. For the entire account from a plurality of views, see Brading (1985, 1988, 2001), Castillo (1996), Elizondo (1997), Glantz (1995), Lafaye (1976), Maza (1953), Nebel (1995), Pallares (1981), Rodríguez (1994), Siller, Glodomiro (1989).
} 
someone observes a dozen times that the Wittgensteinian form is a 'Rabbit'. Then, in a distinct context, or perhaps not, a radical perceptual switch might occur such that the drawing is suddenly reported as a 'Duck', and with this thirteenth observation its ambiguous nature finally becomes apparent to the observer. With respect to Wittgenstein's 'Rabbit/Duck', suppose Netherworlder has the following set of signs:
Dabbit
$=$ examined before $\mathrm{t}_{\mathrm{o}}$ (which is arbitrary) and reported to be a 'Rabbit', or not so examined and reported to be a 'Duck'.
Ruck

$$
\begin{aligned}
& =\text { examined before } t_{\mathrm{o}} \text { and reported to be a 'Duck', } \\
& \text { or not so examined and reported to be a 'Rabbit'. }
\end{aligned}
$$

Assume somebody from Ourworld is capable of seeing the drawing only as a 'Rabbit' - in other words, he is not cognizant of the drawing's ambiguity. Netherworlder, in contrast, sees the drawing as one thing — which is the equivalent of Ourworlder's 'Rabbit' — prior to a particular moment. Then, after that moment, she reports it as something else entirely — the equivalent of what would be Ourworlder's 'Duck', were she able to see it in the drawing.

Netherworlder would obviously be as far as Ourworlder is concerned rather naive and whimsical, changing her mind, signs, and perception apparently at the drop of a hat. Naturally, of course, Netherworlder believes this is not the case at all. She merely perceived something as what was for Ourworlder something else at a given time, and in so doing attained what is for Ourworlder an alternate (that is, a nutty) level of awareness, and that's that. The important issue is, however, that the so-called alternate level of awareness must be for Netherworlder irreversible (discounting memory loss, of course). The time at which phenomena are observed, then, can determine 'truthvalue' and meaning with respect to those phenomena. What is considered 'true' at a particular time depends upon expectations derived from memory of previous experiences. However, when those expectations are not satisfied, discovery of a new form of 'truth' and meaning — and of ambiguity in the 'Rabbit/Duck' case — is potentially forthcoming (for further along these lines see Merrell 2004).

This, I would respectfully submit, is the process our Indigenous people from the Valley of Mexico were caught up in. The Spaniards 
continued to distinguish between Guadalupe and Tonantzín; the Amerindians fused them to create an image hitherto unknown, Guadantzín (or Tonalupe) after $\mathrm{t}_{\mathrm{o}}$. The Spaniards' world conformed to their bivalent categories, and the twain between must never meet; the Amerindians brought forth a new sign from within the Guadalupe/ Tonantzín pair of terms, thus violating the Excluded-Middle imperative. But their image, Guadantzín (or Tonalupe) could have been for them, after $\mathrm{t}_{\mathrm{O}}$, as clear and distinct an image, and as distinguishable from either Guadalupe or Tonantzín, as was the Spaniards' pair of images, one sacred and the other heretical. The very fundamental nature of this semiosic process is that now there were three images, and potentially four different terms, rather than the original two.

Signs grow, and in so doing they breed complexity, a complexity bearing witness to a pluralism of worlds. ${ }^{9}$ Let us hold the GuadalupeTonantzín-Guadantzín story in abeyance, while we look at some further implications for cultural semiotic processes

Logical principles, and conundrums of deductivity

Problems at the core of classical thought now loom large. Eventually, the bivalent model of classical logic threatens to fall in a heap, for inconsistency and contradiction eventually raise what the wellgroomed logician considers their ugly heads. As inconsistent, a given translation - or body of knowledge as it were - shows itself to be overdetermined, for a host of possible alternate translations are always somewhere, as semiotic possibilities, ready and waiting to replace whatever translation happens to be in the public eye within a given spacetime context. In other words, from within a given horizon, local consistency may seem to rule. But at the global level, when any and all cultural horizons, possible and actual, are ushered onto the scene, inconsistency inevitably becomes immanent at some point or other.

9 In a comparable vein, Terry Eagleton (1996) writes that postmodernism is "a style of thought which is suspicious of classical notions of truth, reason, identity and objectivity, of the idea of universal progress or emancipation or single frameworks, grand narratives or ultimate grounds of explanation" (viii), and that against the Enlightenment ideals, postmodernism "sees the world as contingent, ungrounded, diverse, unstable, indeterminate, a set of disunified cultures or interpretations which breed a degree of skepticism about the objectivity of truth, history and norms, the giveness of nature and the coherence of identities" (vii). 


\section{Floyd Merrell}

Absolutely clear and distinct translations, from one horizon to another, from one language to another, from one theory to another, or in science from observation sentences regarding perceived phenomena to theoretical statements, are generally considered to become, as we shall note below, difficult, and at times well-nigh impossible. It is as if one culture and its respective language roughly had meaning ${ }_{1}$ for a given word, while another culture roughly had meaning 2 for what appears to be the equivalent word. Yet the two meanings are radically at odds. How many cultures and languages and meanings can there be anyway? Many, virtually uncountable many, pluralistically many. How can meanings in one language be mapped onto meanings from another culture? They can't, at least in a Cartesian clear and distinct manner. The upshot is that any and all translations are inevitably incomplete, and underdetermination rules, for within some timespace context some alternate translation will emerge into the light of day that will be deemed more adequate and hence it will replace the translation that was previously given a favorable nod. Each translation is a generality regarding the target text, and as a generality, incompleteness always inheres.

Disconcerting, all this. It reminds us once again of Gödel's unexpected and often unwanted incompleteness theorems. To make matters worse, in 1936 Alan Turing demonstrated that there is no mechanical procedure that can decide in advance if a computer program will be capable of a given task or not; if it will 'halt' or not. And yet,...

The problem complexifies even further: toward radical pluralism

In the 1950s Gregory Chaitin convinced a growing number of physicists, mathematicians, and logicians that not only was David Hilbert just a little bit wrong - in his contention that a finite set of axioms could be written capable of accounting for the whole of mathematics. It's actually much worse than Hilbert ever imagined. There are extreme cases, namely regarding the matter of randomness, where the idea of mathematical truth has no structure at all, where it's completely unknowable, where it's merely accidental, where mathematical truths are no more than a coin toss, where they are true by accident for no apparent reason. 
Chaitin himself tells us that Gödel surprised us with purely formal incompleteness, and with Turing incompleteness took a turn to concrete mechanical issues, but with his - Chaitin's - work, given the infiniteness of any and all possibilities when considering the totality of all possible programs, randomness and pure chance inhere, and wherever we turn we smash against a brick wall because incompleteness hits us in the face (Chaitin 2001).

What we have in terms of this expulsion from the inductivity and deductivity paradises, given the work of Hempel, Goodman, Gödel, Turing, Chaitin - and many others too numerous to discuss here - is enough to put a scare in the most stalwart mathematicians and scientists. Inductivity allows for an uncountable number of world versions, each of which, locally speaking, can be either true or false, according to the eye of the beholder. But by putting a collection of world versions into the same mix, we inevitably end up with more than merely a few inconsistencies here and there. Deductivity allows for what appear to be clean and consistent premises, methods and strategies. But within some unforeseen timespace context, some alternative to the commonly accepted system of thought and perspectives will pop up and throw us into turmoil, for this new system appears superior to the old one. Taking all systems of thought and mind into account, past, present, and whatever might emerge in the future, we must concede that, globally speaking, the truth lies in neither the one nor the other system of which we have some modicum of knowledge, but in some other system awareness of which we do not yet enjoy.

\section{And yet,... and yet,... should we really fret over it?}

In fact, if we conflate the above words on Peirce with the problems of induction and deduction, it might appear that we are going from the frying pan to the fire. ${ }^{10}$ But are we really? Let us construct and contemplate something in the order of Figure 3.

"Why complicate the issue?" comes the immediate protest. I would contend that the issue is indeed complex, and to reduce it to simplicity brings on other complications the likes of which we have haven't yet

10 Actually, Peirce has a third term, abduction, which corresponds to Firstness, while abductivity pertains to Secondness and deductivity to Thirdness (see Queiroz, Merrell 2005). 
seen and would rather not see. Actually, Figure 3 affords us an image of the processual — and hence Peircean - nature of homogeny, hierogeny (autogeny in conjunction with hegemony), and heterogeny. I end these terms with the suffix '-geny', since, of the same root as gene, it elicits the image of genesis, organicity, and process, and it falls in line with the processual nature of semiosis. I use the prefixes, 'homo-', 'hiero-', and 'hetero-', respectively, as: (1) 'same', 'like', or 'analogous to', (2) 'positioned or ranked', with priority given to one term over the other one, and (3) 'different', 'dissimilar', 'diverse'.

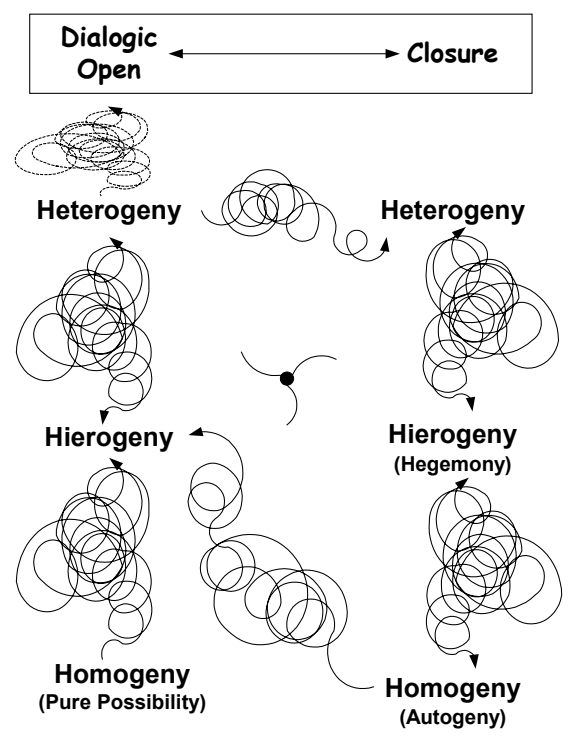

Figure 3. Processual nature of homogeny, hierogeny and heterogeny.

On the right side of Figure 3 we have dialogic openness and on the left side closure. In the center we have the swirling, swiveling legs of the Peircean semiotic tripod. From the bottom left to the top we have possible passages, that can be either two-way or one-way, depending on the circumstances, and the same condition exists along the right side. At the upper portion of the diagram we have one-way passage from openness toward closedness, and at the lower portion we have a possible passage upward toward the left side. 
So, what's the figure all about? The emergence of somethingness from the sphere of pure possibilities at the lower left to somethingness in the center to successive differentiation at the upper left. Something emerges out of homogeny, as a First. This is left-side homogeny, as pure possibility, capable of holding possible signs and their contraries, complementarities, and contradictories together as unruly but complacent bedfellows. Obviously, the Principle of Non-Contradiction has no place in this rippling, effervescent sea of apparently chaotic options there and waiting their chance to be selected and chosen to emerge as candidates for signhood. And in the process something is emerging, into hierogeny. Then, we label it as either one thing or something else, as a Second. As a Second, it has been duly classified as something or other rather than something else, which it might have been, had the conditions been otherwise, hence it becomes a Third. (For example, a Ptolemaic scientist would label the 'Earth' the center of the universe, while for his Copernican counterpart that label would belong to the 'Sun', and today's scientist would attach the label to something else entirely.) Within Thirdness, we become aware of the subtle variations by which this Second is differentiated from all other Seconds in its category and from all Seconds within other categories. (The Ptolemaic true-believer knew the 'Earth' is the center of the universe because of such-and-such a set of premises and their conclusions; the Copernican would have a different and contradictory set of premises and conclusion; for the contemporary scientist the nature of the universe is something altogether different.) Since Thirdness has entered into the light of day, everything is out in the open, and subject to subtle and occasionally to radical changes, given their nature as Thirds.

And all of us, within our culturally embedded contexts, usually manage to get along. In fact, we might get along so well that we tacitly assume the way we perceive and conceive and label our world is clearly and distinctly the way the world $i s$. This is to say that we are now in the process of closing the doors to novelty, to creativity, at the right-side of Figure 3. Consequently, heterogeny becomes fixed; programmatic hierogeny becomes hegemony - and may the 'best man' win; that is, homogeny is on the road toward becoming autogeny our thought and perceptual and conceptual patterns and actions are becoming virtually fixed. Now, only by a radical change of heart and mind - a 'paradigm switch' if you will — some iconoclastic and enterprising soul might be able to take a strong swim against the 
current, enter into the light of day once again, and experience dialogic openness by taking that wild ride from right-side homogeny to leftside hierogeny.

\section{Fret over it or not, this is our condition}

Now consider Figure 4, since it can illustrate what I have in mind better than I can say it. Homogeny left, overdetermined and of utter vagueness, is what 'might become', within some timespace context. Hierogeny left consists of what is what it is, or at least so it appears to us. It makes up our world, the world we have come to know and with which we are familiar. It is the world we've made; we've made it as much as we've found it; it is invented and fashioned rather than merely discovered and explored as if it were something 'out there' for our taking.

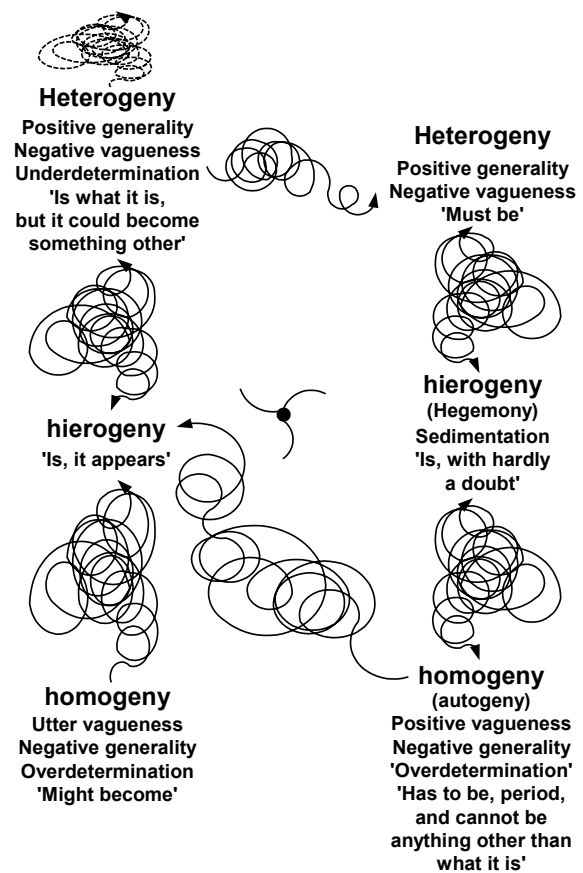

Figure 4. Positive and negative generality, positive and negative vagueness, underdetermination, overdetermination and 'overdetermination' in the processual model of homogeny, hierogeny and heterogeny. 
Heterogeny left is underdetermined positive generality, where one takes what one thinks is as it is, with acknowledgment that at any moment it could be in the process of becoming something other than what it was becoming. It is of positive generality insofar as there is such awareness that the world could be other than what within our particular timespace conjunction we take it to be. It is also of negative vagueness, since under ordinary circumstances we tend to embrace our set of conceptual categories or generalities and conveniently ignore the inevitable tinge of vagueness and ambiguity, or fuzziness, in all our conceptual schemes. And we improvise, at least until our fallibilism catches up with us and we begin looking for some alternative to what has become a glitch in our knowing. Heterogeny, hierogeny, and homogeny right depict progressive fixity of the leftside processes, as described above. Since our overriding tendency, within our community, is to assume we are more right than wrong, and if we encounter few instances that would lead us to believe otherwise, our knowing and our travels through the pathways of our everyday living become increasingly entrenched, sedimented, stabilized. Thus we begin gravitating toward hegemony-right. There, negative generality resides alongside positive vagueness. Negative generality is that which is merely potential, and positive vagueness is that which would otherwise be vague. But since negative generality is the merely potential that due to sedimented, entrenched, habituated action and reaction has become mindlessly perceived and conceived as the world that is, within that world, what is 'overdeterminately' actualized from Firstness is taken as static, permanent — and processual becoming remains frozen. ${ }^{11}$

In sum, homogeny-left is overdetermined, and populated with inconsistencies, given its nature as utter vagueness. Hierogeny-left is the sphere of bivalence, wherein Identity, Non-Contradiction, and Excluded-Middle find themselves in congenial company. Heterogenyleft is underdetermined and perpetually incomplete. On the opposite side of Figure 4, homogeny is 'overdeteremined', which, unlike overdetermination on the left-side, is not a question of virtually unlimited

11 According to the premises underlying Figure 4, and in view of my suggestion in footnote 3, 'overdetermination' must be distinguished from overdetermination. The former is comparable to Freud's use of the term; it is the product of compulsion. The later, in contrast, offers relatively free-wheeling possibilities of choice according to the timespace conditions that might happen to inhere. 
possibilities within a diversity of timespace contexts at all, but rather, it is hard-driven by a compulsion to jam-pack everything into a set of fixed categories of thought and action-reaction. Thus what is actualized, hierogenized, is what is, with nary a shadow of a doubt. What might have been openness along the left-side has become closure on the right-side.

In view of Figure 4's nature of $i-i-i-$, Sandra Rosenthal (1994) effectively argues for Peirce's concept of vagueness and possibility as vagueness of positive possibility and vagueness of negative possibility. Negative possibility is Firstness in the most general sense: left-side Firstness containing all possibilities at all possible times and places, the vast majority of which lie outside critical common-sensism at a particular time and place (the Aztecs' initial confrontation with Guadalupe). Positive possibility is Firstness in the vaguest sense: right-side Firstness limited to tunnel-minded thinking that disallows alternatives other than those permitted by sedimented ways and means (the Guadalupe image the Spaniards wished to impose on the Aztecs). It follows, Rosenthal suggests, that there must also be varying degrees of both positive and negative generality, and since there can be no generality without vagueness and no vagueness without generality, there must be generality of Firstness as well as of Thirdness, and vagueness of Thirdness as well as of Firstness (this opened the door allowing the Aztecs to slip a dose of resistance into their outward show of conformity).

Utter vagueness is overdetermined possibility in the most general sense. This is negative generality, since nothing has been actualized to take its place as a generality in the positive sense. What is actualized on the left-side becomes the world of appearances that, underdetermined in terms of positive generality, can at some point give way to some alternative or other (and the Aztecs could create their hybrid image, Guadantzín). A move to the right-side yields positive generality as a dogmatic 'must be', with little inclination to entertain the possibility of alternatives; then, gravitation downward breeds closed, entrenched, and more dogmatic and even hegemonic certainty. Finally, sedimentation settles down to negative generality and positive vagueness, of the 'overdetermined' sort - but now in the sense of Freudian repression, hence the scare quotes - that demands a definite set of canned action and reaction modes to whatever situation happens 
to pop up (that, of course, was the ultimate goal of the conquerors, the Spaniards).

Acritical knowing finds itself on the right-side. Before it can become critical, however, it must bring about the swinging, swirling voyage to the left-side, where the horizon is open to view and a proliferation of alternatives emerge. Then, and only then, is it possible to keep the interpretative process alive. If one remains on the rightside, cut-in-stone knowledge is the order of the day. But this would be 'semiotic death', as far as the interpretative process goes. For, what keeps the process vital is a proliferation of alternatives along the semiosic stream (and the Aztecs took advantage of one of the possible alternatives they had at hand).

Pluralism. It perplexes, and it entices, given the freedom it offers.

\section{When the semiotic gusher is at its best, what are the consequences?}

The very idea of pluralism lends itself to a multiplicity of interpretations, which is to be expected, of course, given the nature of pluralism: a pluralism of theoretical possibilities would appear to be the only feasibility. Or perhaps better, we should try for a pluralism of theory versions (Rescher 2004: 79). As Rescher argues, pluralism admits to in the very least to four versions (see Table 1), which I've altered in order to render them congenial to the above words on Peirce's concept of the sign.

Let us integrate this table with Figures 3 and 4.

1. Dogmatism, takes its place within a system of authoritarian hegemonizing force. It is an outgrowth of heterogeny-right; it has universalized one particular world version that has become dominant, and the standard to be imposed on oncoming world versions. The dogmatic mind can be dangerous, as it tends downward, threatening a totalitarian homogenization of all world versions and patterning them after the dogma.

2. Doubt and denial, or Radical negativism, has its beginning prior to the left hegemonizing side, where no world version that can possibly be actualized has yet been adopted. This is the good news. As long as an open, dialogic spirit prevails, a host of possibilities are available for adoption. However, a move to 
right-side heterogeny by the potential dogmatic mind introduces us to the bad news: skepticism in its most radical form can infiltrate, become entrenched and sedimented, and then solidification and dogmatic closure threatens. When this occurs, no world version has a chance of realizing its self-organizing tendencies, since it will be rejected as soon as it is made known; subsequently, everything must be sent on its linear, tunnel-minded road toward homogeny-right.

3. Syncretic relativism can find a home within hierogeny-left, as it enters into the process of heterogeny. The problem is that, as syncretism, it consists of a mix of world versions but there is no genuine fusion; hence the individual properties of each world version remain by and large identifiable. Syncretic relativism is no more than a salad-like concoction, and it will remain so, because the diverse elements cannot, or at least have not yet, interdependently merged into one another to bring about the creation of something different, something new. In this manner, genuine heterogeny stands hardly a chance of effectively carrying out its role. Syncretic relativism is thus of an 'everything that is, is good, and equally viable' sort. Within its context, as pluralistic concoction of world versions, syncretic relativism can offer hardly anything different and of lasting value. It only presents an array of divergent, and often incommensurable, world versions. As such, since there is apparently no promising alternative that can be embraced and adopted, the tendency is toward the right-side, where dogmatism attracts and entices.

4. Contextualized novelty seeking relativism emerges from homogeny-left and flows into heterogeny. It is a perspectival contextualist view that is capable of fusing a plurality of world versions (of the Goodmanesque sort we saw in the Aztecs case), in the process create finer and finer differences such that the tendency is toward homogeny. But not quite, for, in the first place, since two or more world versions have become fused, syncretic relativism and doubt-and-denial skepticism have been left in the wake, as the flow is always toward something novel emerging out there, somewhere, somewhen. And in the second place, there is no longer any tendency toward homogeny-right, since, even though differences become finer and finer, neverthe- 
less, there can be no more than a near-continuity of differences, as fine as the smoothest vanilla ice cream. Genuine continuity is possible, but only in the theoretical long run. Thus novelty seeking relativism can in the best of all worlds move increasingly closer to that of a general world version, virtually in 'semiotics unbounded' fashion (Petrilli and Ponzio 2005). But not quite, for incompleteness there will always be. (Recall the above sections on our inductive and deductive limitations, and the incompleteness and/or inconsistency, as well as the uncertainty, of our knowing, the inapplicability of the classical Principles of Identity, Non-Contradiction and Excluded-Middle with respect to signs of vagueness and Firstness and generality and Thirdness.) $)^{12}$ The dangers of dogmatism, religious fanaticism, doctrinaire political ideologies, hard-nosed scientific paradigm enforcers, and such, I trust, hardly need further clarification. Suffice it to say that the skeptic on the left-side engages in a healthy form of moderate 'negativism', giving virtually any and all world versions a careful look, yet invariably ending up with the same version. The radical skeptic, on the right-side, categorically and closed-mindedly rejects all available options. The left-side syncretic relativist also maintains a healthy

12 At this juncture, a few observations. For Peirce the 'real world' is the world of 'sensible experience' ( $C P:$ 3.527), and 'sensible experience' is the result of perceptual awareness that is given perceptual judgment concerning the nature and content of the percept ( $C P: 5.115)$. In other words, the interpreted percept bears on what is perceived and it is what is 'real' according to the perceiver ( $C P: 5.568)$. As such, what is judged as what $i s$, by and large conforms to the classical logical principles of Non-Contradiction and Excluded-Middle ( $C P: 3.529)$. It involves $i-i$ $i$ - between perceiver and the brute physical world; it is the perceiver's world of 'fact', of 'facts' that are what they are, and at that timespace juncture cannot be other than what they are. However, this world is the perceiver's 'ideal world', for, since alternatives to what for that perceiver is that it $i s$ will always exist - within the general, 'underdetermined sphere' — and can make their play at the most unexpected moments. These alternatives are not forthcoming out of the clear blue sky, but rather, they emerge from Firstness - from within the vague, 'overdetermined sphere' - hence Peirce's notion that the 'real' must be conceived as 'fallibilism objectified' (CP: 1.171). This unification of Firstness and Thirdness with Secondness, and overdetermination and underdetermination, Sandra Rosenthal to suggests, "undercuts the dichotomy of foundationalism or nonfoundationalism and along with it, the closely related dichotomies of realism or antirealism and objectivism or relativism since each of these dichotomies, in its own way, represents the alternatives of an absolute grounding of knowledge or skepticism" (Rosenthal 2004: 207, 209). 
posture of tolerance, generally embracing other particular ethnic, racial, and gendered world versions in an effort to maintain openness to all and all within an open dialogical process. She might even go to the left-hand extreme, endorsing the whole bag of world versions, with a presupposed open-minded pluralism. This is an 'anything goes' mentality that sees good on all sides and tends to endorse the whole lot of world versions might eventually enter, somewhat in the sense of Paul Feyerabend (1975), though his form of syncretism does not go without a critical view of left-field bogus versions.

Table 1. Four versions of pluralism.

\begin{tabular}{|c|c|c|}
\hline Condition & Conception & Assertion \\
\hline $\begin{array}{l}\mathrm{A} !(\mathrm{B}, \mathrm{C} \ldots \text { are } \\
\text { of little to no } \\
\text { consequence) }\end{array}$ & $\begin{array}{l}\text { Dogmatism. } \\
\text { Hegemonizing, imposing one's } \\
\text { version on others through } \\
\text { coercion and domination. }\end{array}$ & $\begin{array}{l}\text { "One and only One } \\
\text { alternative must be adopted, } \\
\text { for that is the way the world } \\
\text { is". }\end{array}$ \\
\hline $\begin{array}{l}\sim \mathrm{A} \text { and } \sim \mathrm{B} \text { and } \\
\sim \mathrm{C} \ldots \sim n !\end{array}$ & $\begin{array}{l}\text { Doubt and denial: skepticism } \\
\text { (and toward cynicism). } \\
\text { Moderate to radical negativism, } \\
\text { carefully appraising world ver- } \\
\text { sions and ending up with } \\
\text { his/her own, or rejecting any } \\
\text { and all world versions except } \\
\text { his/her own. }\end{array}$ & $\begin{array}{l}\text { Either, "I'll look at all alter- } \\
\text { natives with the idea that, } \\
\text { ultimately, no alternative (or } \\
\text { no alternative other than } \\
\text { mine) should be adopted", } \\
\text { or, "I'll categorically reject } \\
\text { all alternatives, for none of } \\
\text { them are adequately viable } \\
\text { (except mine)". }\end{array}$ \\
\hline $\begin{array}{l}\mathrm{A} \text { and } \mathrm{B} \text { and } \mathrm{C} \\
\ldots n !\end{array}$ & $\begin{array}{l}\text { Syncretic relativism. } \\
\text { Holism: an effort to hold all } \\
\text { his/her versions together, and } \\
\text { ideally render them mutually } \\
\text { inclusive, yet his/her inclination } \\
\text { is to remain with his/her world } \\
\text { version. }\end{array}$ & $\begin{array}{l}\text { "All alternatives are to a } \\
\text { greater or lesser degree } \\
\text { acceptable, within their } \\
\text { particular, self-contained, } \\
\text { self-sufficient, self-reflexive, } \\
\text { holistic cultural context, but } \\
\text { I'll stick with my world } \\
\text { version, thank you". }\end{array}$ \\
\hline $\begin{array}{l}\text { neither A nor B } \\
\text { nor C } \ldots n) \ldots \\
\text { but } \ldots \rightarrow \psi \text { ! }\end{array}$ & $\begin{array}{l}\text { Contextualized novelty seeking } \\
\text { relativism. } \\
\text { Emergentist pluralism: fallibi- } \\
\text { lism admitted, and an incessant } \\
\text { search for a more viable } \\
\text { alternative through dialogue } \\
\text { with others and with the world. }\end{array}$ & $\begin{array}{l}\text { "I've provisionally adopted } \\
\text { what appears to be the most } \\
\text { viable alternative, with an } \\
\text { eye constantly open to other } \\
\text { alternatives that within their } \\
\text { inherent context, may prove } \\
\text { more adequate". }\end{array}$ \\
\hline
\end{tabular}


The novelty seeking relativist, remaining on the left-side, admits to her fallibilism, hence she never ceases her effort to further specify, clarify, and validate her knowing, such that it may be in the process of becoming something other than what it was becoming. And to top her quest off, she engages in an incessant search for viable alternatives to her process of knowing. She conducts her knowing affairs with care and caution, hoping for something unexpected around the next bend in the stream; hence she is rarely surprised that she's isn't surprised when something unexpected emerges. In short, the dogmatist hardly takes a serious look at any alternatives, the negative doubter might venture to entertain alternate possibilities, but after a brief appraisal will customarily accept none of them, the syncretic relativist tries his damnedest to hold the unruly mess in one piece, and the novelty seeking relativist circumspectly appraises everything and accepts what she deems most adequate.

Indeed: a pluralism of rivalries. The dogmatist will have nothing to do with any alternative. The skeptic would have us reject virtually everything as irrelevant or inadequate. The syncretic relativist smiles approvingly of virtually all alternatives, insofar as she can keep them interrelative and complementarity, from within her global purview. In other words, she would like to steer clear of confrontations and inyour-face controversy, refusing a negative posture by embracing everything, as if to say that there's no posture she would reject out of hand. For the novelty seeking relativist, as emergentist, no alternative is so wretched that it must categorically be tossed in the garbage can, nor is there any alternative so pure that it is capable of standing the test of time indefinitely. Rather, the search for something a mite better must endure.

\section{Yet, syncretic relativism has its attraction}

Constructionists and many cultural theorists have been attracted to the syncretic view under various guises (hybridism, transculturation), and such, that, in spite of their better judgment, occasional slips into dualistic, and even essentialist, thinking. Granted, they pay due lip service to the evils of 'binary oppositions', and more often than not make good on their words. Yet, there is some tendency to slip into that smug security blanket. At the same time, they keep minuscule differences 
between their opinion and that of somebody else alive, so that conferences, articles, and books can continue to be forthcoming. In their way of thinking, this is what generates and perpetuates pluralism. But actually, there need not be a pluralism of conflicting views; rather, contextualized novelty seeking relativism maintains, insofar as possible, an inclusive concoction of alternatives in check, while always keeping an eye open for whatever might happen to be emerging.

Be that as it may, syncretic relativism holds truth to be sufficiently magnanimous in order to accommodate contradictions without excessive distress. It would seem that, in good Nicholas of Cusa, and later Hegelian spirit, the hallowed Principle of Non-Contradiction can find a comfortable place in the sphere of Truth - which can also be the case in 'logics of inconsistency' and 'paraconsistency'. This conception of Truth sees no problem in encompassing multiple truths and conceding rightness to many rival positions and competing theories. This ecumenical, all-embracing doctrine follows a model reminiscent of a combination of two of Jorge Luis Borges's (1962) chimerical books. One book, which is the objective of his tale, 'The Garden of Forking Paths', contains infinitely self-returning paths. The other book, in the 'Library of Babel', contains a Compendium that lists all possible books that can be composed by all possible combinations of a 25-character alphabet. Just as the Library contains all possible books, each of which must confront its anti-book somewhere, so also the 'Book of infinitely forking temporal paths' is inherently self-contradictory. And yet,... the reality of all books, or of the 'Book of the Universe', so to speak, is a mind-numbing complexity of possibilities (the overdetermined sphere) that, over an interminable expanse of timespace contexts, gives way to the engenderment of a virtually uncountable number of those possibilities (within the underdetermined sphere).

At first glance, Nelson Goodman's 'ways of worldmaking' (1978) would seem to defend a posture comparable to that of syncretic relativism. His preferred term I've used in this essay, 'world versions', lays to rest the demand for one and only one Truth. Instead of Truth, there are many possible 'world versions' one of which can be within the purview of the subject at a given timespace juncture, though in another time and place an alternative 'world version' might be presumed equally adequate; or, the subject can, if she so desires, entertain now one 'world version', now another, and then perhaps even another, 
for the sheer joy of doing so, for purposes of comparison and contrast, or in order to adjudicate between them so as hopefully to remain with the most genuine 'world version'. In this manner, a variety of competing 'world versions' can be entertained, though no concoction of 'world versions' can legitimately be held up as The World (but such a 'God's-eye' view is impossible for finite, fallible mortals). Goodman's competing 'world versions', in this respect, are not really what syncretic relativism is all about for precisely that reason: they are always at odds with one another, and they make their differences known at every opportunity (e.g. the 'Grue' example).

Moreover, syncretic relativism, a form of 'perspectivism', is by no means simply Hegelian dialectics. There is no synthetic embrace of two contradictory views, which is then plagued with its own antithesis, and on and on. There is no synthesis, because there is no dissolution of views, nor is there a fusion of views into a more encompassing view that has taken center stage. There is no grand synthesis for the syncretic relativist, but rather, alternatives are thrown into the same bag, duly entertained, and kept around for good measure, and yet syncretic relativism is considered the order of the day, with full awareness that it is not, and cannot be, the ultimate answer. In other words, to affirm any given alternative is in a sense to negate it, for the process must go on. Syncretic relativism appears generous enough, it would seem. Yet it isn't satisfactory, for the subject can't really have her cake and eat it too; she can't have anything and everything at once and at the same time hold true to her syncretic relativism. What she can do is hold now one alternative whether fresh and new or some combination erstwhile alternatives in her purview, now another alternative, and so on, but not two or more of them at the same time.

Syncretic relativism would like to envision itself as a grand cultural symphony. The problem is that for every melody there are virtually countless possible counter-melodies. The resulting pluralism of cultural rhythms would be closer to a multiply variegated baroque counterpoint. Whatever might happen to appear concordant at an unexpected moment turns discordant; balance and harmony become disequilibrium and disharmony; synchrony veers off along multilinear diachronic streams; consonance turns incongruent; clarity dissolves into vagueness and ambiguity. At times cacophony might seem to erupt. 
Refusing any and all discriminations by accepting everything and anything snuffs out controversy; hence dialogue tends to degenerate into a collection of solipsistic monologues. Over the long haul, the end product is the same as if nothing were accepted, dogmatically. Embracing everything, and in the final analysis there is nothing left to say; accepting nothing, and nothing remains. Openness to all alternatives is as if there were no alternatives possibly replacing what had been in some time past adopted, if only provisionally; closedness to all alternatives is as if there were no alternative worthy of replacing anything else, including that which had been in some time past adopted, dogmatically speaking.

In another way of putting it, acknowledging and admitting all alternate possibilities puts one within the sphere of overdetermination, where Contradictions present no problem, but where there are no differences that make an appreciable difference; so one gets nowhere. Acknowledging and admitting no alternate possibilities leads one to assume the end of the road has been reached, and the pot of gold at the end of the rainbow is there, to be snatched up. But there can be no underdetermination of the novelty seeking relativist sort that entertains the notion of alternatives that may emerge, and the notion that one of them may prove itself a more satisfactory candidate for what had been at some time past accepted.

Summarizing the postures in Table 1 within a pluralist setting, we have:

1. Accept my way and my way only (dogmatism).

2. You might as well accept no way, since they're all most likely fraught with inconsistencies (doubt and denial: skepticism).

3. Accept a combination of any or all of them, as you like, for they are all viable on their own grounds (syncretic relativism).

4. Take what appears most viable from the array of alternatives for the moment, but always keep your options open for something more to your taste in the future (novelty seeking relativism).

\section{Some variations on the theme}

Giving additional thought to the implications of Table 1 raises some perplexing issues. Nelson Goodman's 'New Riddle' introduces us to 
the strange case of the Grueworlders for whom emeralds are 'Grue', the color we would ordinarily label 'Green' up to time $t_{0}$, and thereafter they are what we would ordinarily label 'Blue'. From within the two cultures, that of the Grueworlders and that of Ourworlders, it seems inductively reasonable to project 'Green' (or 'Grue'), into our perception and conception of 'Emeralds'. Eventually, whatever the projection may be, it becomes entrenched, and that's that: 'All emeralds are green (or grue)'. This is our way of classifying the world and it is the only acceptable way (hegemonically speaking, might makes right). Case closed.

But the world of our inductive capacities is not as obedient as we would like. Carl Hempel demonstrates so much: 'All swans are white' can be restated as 'All nonwhite things are nonswans', since the two hypotheses are different formulations of the same proposition. And yet, in spite of Hempel's Paradox, we are usually able to cope. We send and take, and engender and translate signs. We compare new experiences to old ones, and pack signs into the pigeon-holes with which we have become most comfortable. Consequently, we use our conventional sets of categories to classify everything in our world that we wish to select, distinguish, and indicate. If at some moment there is apparently no fit, then some surprise reveals something new. So we revise our 'knowing', make whatever changes that seem most appropriate, and we usually go on with life. In this vein, perhaps virtually any and all color terms, or any other adjectives or qualifying labels attached to substantives, and even those substantives themselves, can no longer be held sacrosanct. Our knowledge of them, and in fact, our knowledge in general, can at the most unexpected turn in the stream of semiosis be up for grabs.

But if we have no iron-clad inductive guarantees, should we not go into denial? Become skeptics? Accept nothing in order to avoid falling into error at some step along the way? Or should we allow our categories to proliferate? How many categories can there be for qualifying emeralds anyway? 'Gro', 'Gru', Gue', 'Gou', and whatever else, according to the whims of our perceptual and conceptual faculties? Are we not pushed to the edge of the terrible abyss of nihilism? Against our better thinking, we might find ourselves gravitating toward the right-side of Figures 3 and 4, toward closedness. Well, then, perhaps we can accept any and all alternatives as at least ephemerally valid on their own grounds. And so we become syncretic 
relativists, more or less embracing an 'anything goes' posture. But in such case, we risk finding ourselves also gravitating toward the rightside, since our obsession for embracing all paths is as closed as any other fixed obsession: the embrace of all ways is but another form of closedness if pushed down the gullet of all oncomers. Should we accept nothing of skepticism and accept everything of syncretic relativism? Nothing and everything, choosing no possibilities and choosing all possibilities and their contradictions? - which is the same as choosing none of them, for everything virtually cancels out everything else. The response should be negative.

Ultimately, solely novelty seeking relativism can effectively keep the door open; it is the only viable way, because it embraces one alternative with the admission that at another time and another place some other existent alternative or some new alternative that has surfaced might be more workable. Does this way deny the possibility of some fusion of alternatives? No. For example, with respect to our Mexican cultural case, one person may choose Guadalupe, the other Tonantzín, and someone else neither of them (the skeptic); someone may syncretically accept both of them in some juxtaposition (Guadalupe-Tonantzín); and yet someone else may opt for merging them together, interpenetrating them and rendering them $i-i-i$ - with everything else to yield Guadantzín or Tonalupe, according to the emphasis. But this is no static fusion, for it is always becoming something other than what it was becoming.

Is anybody's experience really as valid as anybody else's? Is it equally true and compelling? But 'equally true and compelling' for whom? The experiences of others certainly are not equivalent for us - save insofar as we somehow make them part and parcel of our own. Moreover, my own experience, I would like to think, is unique. You surely believe the same of your experience. In any event, if I choose to accept novelty seeking relativism, from within each and every timespace context I have hardly any recourse but to proceed from wherever I happen to find myself. This radically pluralist perspectivism, nevertheless, is the most satisfactory answer; it involves constant improvisation, perpetual creative responses to incessantly altering cultural processes. There is nothing absolutely given in advance, nothing that we are endowed with as if ex nihilo, nothing that we can justifiably presume, or presuppose, no preconditions on the basis of which we can act. There is only the 
moment, right here and now. By the time we can conceptually prepare ourselves to take action, the background of our experience has already begun becoming something other than what it was becoming. By the time, in that next moment, we got to the point where we thought we were proceeding, that point has become something else. We cannot know where and when we are, and we cannot perceive and conceive what there is as if from 'nowhere' (that God's-eye view again). Nor are we in a vacuum with respect to our myriad perspectival takes on ourselves, on others, and on our world. Yet, we always enjoy some position; we cannot maneuver in our everyday existence without some position or other, however ephemeral it may be.

But another question emerges: Is this experience always from somewhere and somewhen not also some sort of absolute? As such, does it not range over time and space to afford us ephemeral grasps of that absolute? And if so, then is it not as absolute as any other absolute? No, because there are always complementary contextual possibilities as alternatives to whatever we have at hand. Well then, to pose Rescher's (2004: 117) questions: 'Does not contextualist pluralism put everyone's position on a par? Does it not underwrite the view that all the alternatives ultimately lie on the same level of acceptability?' Once again, we must ask: Acceptability for whom? The response, I would submit, should be: Acceptable for each individual, for $\mathrm{s} / \mathrm{he}$ is committed to her/his own set of experiences. This, once again, involves a pluralism of multiply diverse postures.

\section{Comes another counterargument}

It appears that the form of pluralism I am advocating stands little chance of getting anywhere, since, in spite of my better judgment, it places all competitive views on equal footing. Not really, however. Pluralistic novelty seeking relativism admits to some merits, however minimal, in any and all views, and, in addition, it holds that any and all views are fallible, hence no view is absolutely without faults.

No view gets everything entirely right for all time, for all views at some time and place or other will reveal some flaw. Indeed, pluralistic novelty seeking relativism resists the temptation to reject rival views outright before they have been duly appraised. It also struggles against gullibly accepting any view straight and without a chaser. There is 
discrimination here, but with the idea that whatever looks good today might become ugly tomorrow, and whatever appeared hideous yesterday might take on a rather attractive countenance today. The watchword? Neither dogmatic dismissal nor blind reception; neither total tolerance nor intransigent intolerance, but rather, judicious contemplation and evaluation and selection of what is at hand today, with the expectation that the next day will likely place things in a different light.

This is to say that just as the pluralistic novelty seeking relativist would advise others to abandon whatever position they might have held when some more promising alternative happens to come along, so also she would advise them never to cease seeking more enticing alternatives, within ever-changing contexts and circumstances. In this case one should never view one's position as superior to other positions, whether actual or possible. Either there are many future possibilities, and the idea that any possibility is determinately better than all others does not come up, or there is only one possibility that is determinately better than all others, and so the search for that possibility has no end point. If contexts and circumstances are indeed ever-changing - and given the premises underlying this essay, they are - then the search for the ideal superior possibility will never cease; hence there is no knowing absolutely whether a given possibility within some particular timespace context might be precisely what the search has been all about. So in the final analysis it might appear that you can eat your cake according to your heart's desire, but you can never have it in its entirety.

Yet, I would respectfully suggest, one must take a stand, choose sides, decide who is friend and who is foe. And one must defend oneself against those who disagree. If the critic turns out to be dogmatic, a nay-saying skeptic, or an open-arms relativist, one might consider intolerance toward the intolerant, temperance toward the 'nothing cuts it' crowd, and deference toward the 'virtually anything goes' gang. Above all, the search for something better must always go on. And decisions must be made. Buridan's thirsty and hungry donkey that couldn't decide whether to go for the hay to the right or the water to the left is no model to emulate. Nor should one look for some shade of grey as the ideal. From within the timespace context where and when one happens to find oneself, a decision must be made, for the here and now. And if one perchance chooses well, given the general 
conventions within one's community, then one might be able to enjoy communing with others for another day.

In this vein, the proper path is: homogeny-left signs emerge, as a consequence of complementary co-participation between sign makers and takers and the signs themselves, in $i-i-i-$. Then, differences that make a difference appear, variations on the signs's original theme make their play, and movement tends toward heterogeny-left. Eventually, a tendency toward smugness, toward unwarranted certainty seeps in, and heterogeny-right beckons, offering the security of likeminded and therefore right-minded thinking and doing. But beware. Once on the right-side, hierogeny-right and hegemonic practices, and with them, entrenchment, and tunnel-minded certainty can come to dominate. Dogmatism may soon raise its ugly countenance, and closure exercises its force. The answer? Keep everything open, insofar as possible, at heterogeny-left.

However, objections are still forthcoming: It would seem that my heterogeny-left would entail a perpetual state of dissensus, with no possible consensus. At best there would be no more than some form of syncretic relativism, and at worst there would be a disgruntled atmosphere of doubt and denial, or skepticism. In order for the creation of a coherent, congenial communal state of affairs to come about, there must be a move to the right side, must there not? In order for this community to be self-perpetuating, it must bear some system of values, within the hierogenic mode, which would at least tend toward homogeny-right, but, hopefully, without degenerating into some dogmatically imposed homogenous doctrine.

As reasonable as this sounds, it doesn't quite hold water. On the one hand, heterogeny-left allows for a tolerable degree of dissensus. This isn't to say that it falls into rampant negativism and syncretic relativism, because the most proper hierogenic mode is on the leftside. Hierogeny-left provisionally adopts a global view by means of which local level dissensus can usually be moderated. When moderation appears unfeasible, then global premises, proclivities, presuppositions and preconceptions may be placed in question, and in dire cases that global view may give way to some alternative or other. This condition exists only in the presence of open dialogue, openness to the overdetermined sphere of homogeny-left, and a level of tolerance for contradictory possibilities that can seep up through the Included-Middles within heterogenic-left processes. Nevertheless, a 
move upward and toward heterogeny-right cannot help but tend toward doubt, denial, and skepticism, and then toward dogmatism. When this occurs, dissensus is eradicated whenever possible, consensus is enforced according to those who hold power, doors are closed to dialogic exchange, any and all Contradictions are barred, and the Excluded-Middle Principle is invariably honored.

\section{Others, and their cultural contexts}

Within a pluralistic context, taking the open, self-correcting nature of knowing into account, some degree of incompleteness, hence indeterminacy, and more often than not inconsistency, will sooner or later make their presence known. For what will be one's knowing within some future timespace context will be quite different from what one at present (thinks one) knows. In this manner, our knowing is always restricted by the world version within which we dwell and within which we perceive and conceive ourselves, others, and our physical world.

This knowing involves the whole of our perceptual capacities, and to boot, proprioceptive, kinesthetic and somatic knowing; it is a matter of feeling and sensing in addition to more explicit dialogical and discursive knowing. The problem is that, for some neo-pragmatists, namely, Richard Rorty (1979, 1982), our knowing, and hence our world, is taken as nothing more than a bundle of sentences - a giant step beyond David Hume for whom we are nothing more than a bundle of sensations. Rorty calls this form of knowing 'textual idealism' - a sort of 'language-centered' alternative to George Berkeley's 'subjective idealism'. If we accept this posture, we're in trouble. For we will be ignoring bodymind feeling and sensing at its most concrete; that is, we will be by and large ignoring iconicity and indexicality, while our focus will remain on hypertrophied symbolism. ${ }^{13}$

This is to say that statements about the world from within hierogeny-left can be true from a particular perspective, but percepts and concepts regarding the same world are not necessarily true regarding

13 For further on the topic of proprioception, kinesthetics and somatic knowing, along with a critique of 'textualism', see Merrell (2003), and especially Shuster$\operatorname{man}(1992,1997)$. 
statements from some other perspective (they true for us, but not necessarily true for others). Rorty would like to keep the conversation between ourselves and others and our physical world open, so we can come to an agreement about our percepts and concepts. The problem is that the other minds out there occasionally tend toward authoritarianism. This means that they might wish dogmatically to make their statements true and the statements of others false, which might lead to discrimination, racism and fascism. And great harm could be meted out to the weak by the strong, who are strong, because they were most effective in pushing their way around. All this entails a move toward hierogeny- and hegemony-right. But we don't have to share beliefs with or agree with others in order to understand them. We can to a greater or lesser degree understand them, yet tolerate them in our disagreement.

How can we be sure we can understand them? For example, how do we know that Ptolemy and Copernicus were talking about the same Earth and Sun we talk about? They're not here to tell us so. How, then, can we be so confident that our Earth and Sun are either the same as or different from theirs? How can we know if Joseph Priestley's 'dephlogisticated air' is the same as or different from Henri Cavendish's 'oxygen', or our 'oxygen' for that matter? How can we know in the twenty first century whether Guadalupe and Tonantzín were distinct, fused, or merely confused, in the minds of the conquered Aztecs? And how is it that I can with such facility coin the agglutinated term 'Guadantzín' to depict the Amerindians' perception and conception of their venerated image? Answers are not easily forthcoming. But, if answers there must be, I would expect they would involve differences with respect to how the world is perceived and conceived by way of feelings and sensations with respect to Peirce's Firsts, of perceptual inferences with respect to Peirce's Seconds, and of conceptual inferences with respect to Thirdness. Before one can approach others and their cultures, one must become engrossed, through bodymind feeling and sensing at its most basic, with: (1) one's immersion within one's own cultural flux and flow, (2) one's culturedependent, conventional practices regarding one's community and one's physical world, and (3) one's notion of a generalized set of interpretative modes according to the presuppositions, predispositions, and prejudices, and the conventions and norms, of one's culture. 
One finds oneself within one's conventions and norms, acknowledging and embracing them in part explicitly and in part tacitly. These conventions and norms are virtually self-sufficient yet selfcorrecting, self-contained yet open: they are by no means autonomous, fixed, wholes. However, even under optimal circumstances, there is no unchanging, well-formed and presumably universal consensus with respect to one's conventions and norms within one's community. There is no set of like minded and presumably right minded individuals, homogenized by coercion, propaganda or brainwashing. Rather, there is a bubbling mix of behavioral patterns, ways of feeling and sensing, and modes of perception and conception. There is an open, almost free-wheeling exchange of opinions and ideas, often bordering on conflict and struggle. Under these conditions, there may be pursuit of communal consensus, for sure. And there is the desire for balance and harmony, relatively free of discord, dispute and wrangling. Who wouldn't wish for substantial agreement among members of a benign and enlightened community?

However, substantial agreement among members of one's community is a far cry from beginning to understand others within their community, and it is even further from the dream of consensus.

\section{Yet, is it not possible to understand others?}

How does one find one's place, and the place of others, within one's community? This problem should precede talk of consensus, and even more so with respect to points of contact, and the possibility of some consensual view, concerning vital issues across cultures. When one is within the flux and flow of one's cultural world, given its complexity, its pluralism, then, and only then, can one effectively hope to enter the flux and flow of some alternative to one's cultural world, or of some alternative cultural world. And one might hope that understanding between cultures is possible through some sort of tacit agreement or consensus between members of those cultures.

Jürgen Habermas's $(1971,1979)$ communicative project to complete modernity's enterprise often sees consensus regarding our community, or our community and other communities, as a realizable goal. He would like to avoid Hegel's notion of evolution toward the ideal order by more or less adopting Peirce's idea of an asymptotic 
approximation toward consensus. What is meant by an 'approximation toward'? The asymptote gets nearer and nearer to the finish line, but the increments remaining to be traversed become finer and finer, such that termination of the increasingly torpid trek will occur only at the infinite stretch. Commensurately, for Peirce, consensus, knowledge of the truth, or the end of science as it were, is available solely to some infallible and immortal individual, or to a community containing and infinity of individuals. So we finite, fallible humans will never reach the ideal. However benign Habermas's social order may be, if we take Peirce at face value, it will never be so harmonious, so complete, and so consistent or free of contention and strife, that there will be nothing more to be done. The commonsensical notion among members of a given community that the goal of consensus is the way to go is admirable, and it can provide for a healthy exchange of ideas and modes of behavior. But if expectations will settle for nothing short of consensus, frustration will surely be the virtually inevitable yield.

The problem with the idea of consensus is that, no matter how satisfactory it might appear, sooner or later some degree of dissensus will enter the scene (Rescher 2004). This is both the boon and the bane of diversity, of plurality, of differences that make a difference. 'Like minded' and 'right minded' thinking and talking and behaving might take on the trappings of an ideal community, even of a democratic community. But divergence, discord and disagreement will always be just around the next bend in the road. Tolerance is called for. And if practiced, there will nevertheless be some indication or other of some degree of intolerance. Reasonableness is called for. Yet irreason will tend to emerge here and there when least expected. And reasonableness will eventually show some unreasonable countenance. Some degree of dissensus, dissonance and divergence is inevitable. This should be no call for alarm, however. Disagreement within pluralism can be applauded, that is, if those who disagree are willing to enter into open-minded dialogue. This is a matter of acquiescence within disagreement, however, not subservient acquiescence; it is acquiescence, but with openness toward alternatives, and when a viable alternative presents itself, even if it appears to flow against the grain of the communal current, the option exists that some degree of resistance may be forthcoming. In this regard, there is never complete uniformity (homogeny), but always some element of dissonance and diversity (heterogeny), that perhaps at various juncture may threaten 
to erupt into conflict and perhaps even chaos - but every measure must be taken to prevent this.

Another problem with consensus is that its pursuit is by and large counterproductive - if consensus could somehow be achieved, the desire to achieve success of one's ideas and interpretative strategies over those of others would abate - and it is unrealistic - since total consensus can't be achieved, why waste time striving to reach it? The pursuit of excellence and the desire to succeed more likely than not exists within a context involving diversity and conflict: pluralism. This relatively benign form of diversity and conflict is most notable along the left-side of Figures 3 and 4, since the supreme goal of the dominant haves on the right-side is to hammer the subordinate havenots into shape so as to homogenize society, thus reducing diversity and conflict and creating, through dedifferentiation, conformity and passivity.

Still, in spite of the inevitable pushes toward right-side homogeny and consensus, dissensus there will always be. The telling tale is whether a given society, or two different societies, both at the local and the global levels, can maintain a healthy degree of tolerance in a diverse social milieu consisting of high levels of free thought and expression and at the same time exact a sufficient degree of mutual acceptance of and accommodation to traditional and established standards, values, and modes of conduct. In other words, pluralism need not end up in chaos.

\section{Back to the vortex}

The fact is that, whatever mutual acceptance, accommodation, and conformity there might be, intellectual, cultural, and social progress is often accompanied by resistance and rebellion, whether through print or by violent protest, against complacent, conservative dominant groups. And from whence does this resistance and rebellion flow? From the sphere of possibilities, emerging into the swirling, fluctuating, undulating, scintillating semiosic process at the lower leftside of Figures 3 and 4. In fact, those figures are calling out for another look in the form of Figure 5.

We see the morphological lines of flowing transition between terms and from column to column. We see the radical break from 
homogeny-right to hierogeny-left. And we see something new: the process of dyadism becoming triadism and triadism pluralism, and vice-versa, finally to monism. The sphere of possibilia embraces everything, the range of all unselected possibilities plus those paltry few that have been selected and actualized into some cultural milieu as hierogenous, and perchance Manichean dualistic distinctions, while that which remains unselected and within the nonselected awaits its selection at some propitious future moment or other. Once entering into the processual flow and toward heterogeny-left, cultural distinctions become finer and finer, as changes render them increasingly ambiguous and vague. In other words, distinctions become more and more differentiated until they threaten to become indifference rather than difference. Novelty seeking relativism, provides freedom in an open process to continue on, creating differences that make a difference, no matter how virtually imperceptible they may become.

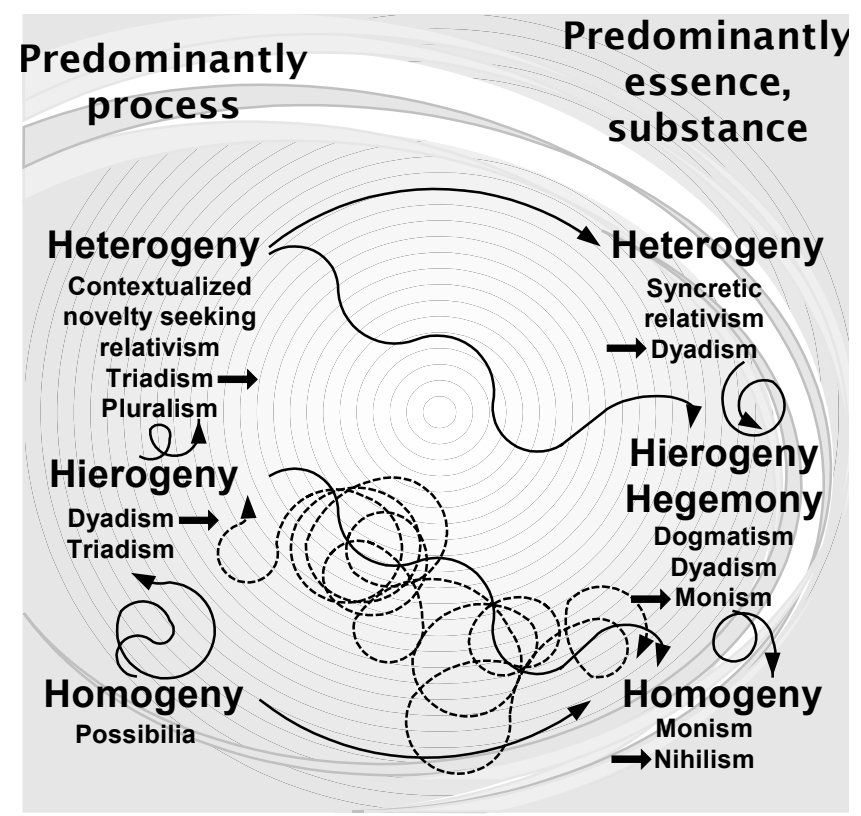

Figure 5. Homogeny left, overdetermined and of utter vagueness, is what 'might become', within some timespace context. Hierogeny left consists of what is what it $i s$, or at least so it appears to us. 
This form of relativism is such that only one alternative would ordinarily be accepted from within a particular timespace context. This is not necessarily based on rationally cogent grounds, but it emerges from considerations of taste, of personal inclination, or social conventions. It is a pluralistic relativism, a relativism emerging contextually, and dependent upon particular perspectival modes created from arrays of cultural contexts; it is a relativism regarding which the community as a whole has created and developed a particular world version that allows for a diversity of variations within the parameters set by that community's set of conventions. This is the 'idealistic' side of Peirce's enigmatic philosophical posture he labels 'objective idealism'. The 'objective' side is found in tempered and guarded relativism - perspectivism, contextualism - according to which only one alternative at a given timespace juncture should be accepted, and this acceptance has a basis of general community agreement with respect to what should be prohibited and what should be permitted. ${ }^{14}$

Left-side heterogenous pluralism, or novelty seeking relativism, tends toward indifferentism. There is maximal diversity which allows different sign makers and takers - and, all the more, different groups and timespace contexts - to adopt different views. The idea that there are a variety of fundamental perspectives regarding the nature of

14 'Objective idealism' at first blush is a strange mix. In formulating his philosophical posture, Peirce is caught in a dilemma. He tries to wiggle out of it by coining the term 'objective idealism'. The concept follows Peirce's notion that interpretants, and our world version they and we have co-participatingly created, involve neither exclusively the material world nor the perceiving and conceiving mind, but a fusion of matter and mind. As Peirce summarizes his notion: "The one intelligible theory of the universe is that of objective idealism, that matter is effete mind, inveterate habits becoming physicals laws" ( $C P: 6.25)$. The physical world is the world perceived in static slices, so to speak, and the mental world creates a flow of these slices from past to future $(C P: 6.127)$. In this light, 'objective idealism' is the Identity principle (regarding interpretants) becoming processual such that there is no fixed identity, and the Non-Contradiction and ExcludedMiddle principles (regarding interpretants) giving way to the becoming of alternatives and their displacement of what was perceived and conceived as fixed. In this manner, 'objective idealism' is comparable to a fusion of methodological objectivism and epistemological idealism: according to our preferred methods and strategies we interact with the phenomena of our physical world and our mental worlds in order to make them more intelligible, but we are repeatedly thwarted in our efforts, and we replace what we (thought we) knew by something we (think we) now know. 
things that engender different positions is thus virtually as old as human societies themselves. Genuine novelty seeking relativism takes things as they come such that from the view of various groups indifferentism can eventually pervade. In this regard, relatively paltry distinctions are of little regard, since, if they are not totally contradictory, then the differences can be smoothed out, and if they appear contradictory, then most likely there is equally no problem, for something new can likely slip through the two horns of the dilemma and emerge as newly born novelty. The advice would be: 'nothing ventured, nothing gained'. Take risks, keep a level head, improvise at every opportunity, and things will have a tendency to work themselves out.

Risks, however, can emerge from three different directions. First, there are risks disrupting the effort to avoid risks altogether. Aversion to risks breeds intolerance toward anything other than what is deemed 'normal' and hence right. This is the dogmatic, hegemonizing attitude, which counsels against taking chances by playing it safe. What is done is the right way, and every other way is wrong. Those who hold this attitude are prone to expect the worst - the natural consequence of skepticism, along the right-side of Figures 3, 4, and 5. A second form of risk involves calculated risk taking. Those who tend to fall into this category have what would seem to be a natural propensity for holding all possibilities in check in order to weigh each one against the others and decide which option will most likely pay the most dividends. This is an expression of syncretic relativism. A third position regarding risks involves caution, for sure, comparable to calculated risk taking, but, in addition, it includes the willingness to seek out new risks with the idea that they will lead to the greatest possible variety of alternatives regarding life situations. This is a more daring calculated approach than the second form of risk taking. It delights in the consequences that ensue from a risky pathway having been taken, and equally delights in the challenge at every step of the way and the need constantly to improvise. Risk seeking takes chances, with eager anticipation and relish, assuming that things will eventually turn out for the best, and if not, it will have been a fruitful learning experience to keep in mind for the next encounter. Such risk taking is a prime example of novelty seeking relativism; it is left-side heterogeny at its best. 


\section{In other words, practice moderation in all things}

Open-minded pluralism, as suggested, does not simply entail an 'anything goes' posture. It is no uncritical acceptance of whatever risk happens to pop up. It is no wild, uncritical embrace of anything and everything. It involves risk seeking and risk taking with care and caution.

Risks are sought out, with this idea that by taking risks and improvising along the way to keep one's head above water, change remains alive and well, and novelty continues to seep up into the open. Whereas the dogmatist and skeptic bar all the available options except the only one that is viable, theirs, and counsel us to reject everything that deviates from the pathway of appropriateness, the novelty seeking relativist moves in the opposite direction, willing and able to reject whatever is at hand here and now for something that might take on the guise of acceptability in the next here and now. Alternatives are brought together, and fused, if possible, in order to draw something new from the fountain of opportunity within the Included-Middle, between the horns of every pair of otherwise antagonistic either/or options.

Novelty seeking relativism sees rival alternatives as equally plausible, until they prove otherwise in the give-and-take of human experience within diverse timespace contexts. That is, a given workable alternative, having emerged from the Included-Middle, can often be capable of accommodating some contradiction or other. If there is lack of self-consistency, then self-sufficiency can overcome the problem, and if not, with the addition of some improvised measures here and there, the problem can often be at least partly ameliorated. This posture conjoins alternatives, and on the whole, life can go on, albeit often to the tune of no more than a syncopated, tenuous balance.

The problem with such tenuousness is that insecurity can enter, uncertainty can make its play, an inevitable move toward the rightside might ensue, and increasing closure threatens, with all its either/or imperatives and shunted hegemony. Subsequently, authoritarian truth, Our Truth, becomes the one and only alternative. Along with truth, the word can tend to become virtually sacrosanct, at the most extreme much in the order of religious rhetoric. The book, consequently, is considered to say what it says, and that's that; forget 
multiple competing readings. And we are flirting dangerously with homogeny-right mandates. However, just as a library contains many diverse books, some of them presenting counterarguments to arguments in other books, others telling stories as variations on themes of other books, and still others creating enticing juxtapositions between themselves and other books, so also reality is a complex concoction of many different and discordant world versions. Each book has its own consistent or inconsistent, and incomplete or presumably incomplete - and if so, inconsistent — organizing style led by its own 'practical reason' (Sahlins 1978). But The World, the collection of all possible world versions, encompasses all possible books, just as the world of our concrete everyday experiences encompasses multiple world versions within our own culture and from culture to culture, as well as all cultures that have been in the past, and all cultures that will have been in the future. Each world version presents its own complexity, and The World as a whole embraces them all without being confined to any of them (Goodman 1978).

This conception, quite obviously once again, entails novelty seeking relativism. One must bear in mind, however, that novelty seeking relativism's fusion of world versions, of perspectives, and of cultural practices, does not involve a collection of elements held together with superglue, while they all retain their former identity. Fusion is brought about from within the Included-Middles, between two or more antagonisms, distinctions, or even minute differences that make an important difference, as something new that nonetheless carries within itself something of the nature of that from within which it emerged. Nothing is absolutely lost, and nothing is absolutely won; there is no absolute gain and the pain is never without some reward. Everything always flows, toward somewhere and somewhen. Along left-side hierogeny and heterogeny, of course.

\section{Wrapping it up with an analogy}

The pluralist view is that of an ongoing soccer game - not basketball, baseball or football, punctuated by lapses between plays, time outs, and such - during which each player contributes to the overall effort, complementing the other players, all of them, to the rhythm of the game. All players are co-participating with one another in the effort to 
get the ball between the goal posts. The players are the melody and the harmony; they are syncopated, now consonantly, now dissonantly, now improvisingly creating a tenuous balance while passing the ball back and forth, now to the left, now to the right, now closer to the goal, now strategically in the other direction, and all the while presenting a counterpoint and an alternate melody to counteract the counter melody their opponents defensively present against their melody in the process of its unfoldment.

Like the soccer match, things don't usually go as planned; in fact, they rarely go as planned - that's why the number of goals during a game is always so paltry. Incompatibility and inconsistency is more often than not the yield. A strategy can end in incompleteness, loss, and frustration, when the opposing team comes up with a surprising countermove. But there's no turning back, no time to regroup, no rest period to map out a new strategy, for the game must go on, processually. There's pluralism, for sure. Each player has her/his repertoire of patented moves, and the collection of players making up the team has its characteristic way of playing the game as it evolves. The team incorporates a 'world version', one version among many within the vast universe called 'Soccer', and after a losing effort, the players might convene for a special session and a pep talk after which they have created a new 'world version'. Then, with renewed confidence, they enter the uncertainty of the next match with a different team. Pluralism, processual pluralism: that, I would submit, is the name of the play, of semiosis.

\section{References}

Almeder, Robert 1980. The Philosophy of Charles S. Peirce. Totowa: Rowman and Littlefield.

Baer, Eugen 1988. Medical Semiotics. Lanham: University Press of America.

Bartra, Roger 1992. The Cage of Melancholy: Identity and Metamorphosis in the Mexican Character. New Brunswick: Rutgers University Press. [Trans. C. J. Hall.]

Borges, Jorge Luis 1962. Labyrinths, Selected Stories and Other Writings. New York: New Directions. [Yates, D. A.; Irby, J. E. (eds.)]

Brading, David A. 1985. The Origins of Mexican Nationalism. Cambridge: Cambridge University Press.

- 1988. Mito y profecía en la historia de México. México: Vuelta. 
- 2001. Mexican Phoenix. Our Lady of Guadalupe: Image and Tradition across Five Centuries. Cambridge: Cambridge University Press.

Brock, Jarrett E. 1979. Principle themes in Peirce's logic of vagueness. In: Brock, Jarrett E. et al. (eds.). Peirce Studies 1. Lubbock: Institute for Studies in Pragmaticism, 41-50.

Carnielli, Walter Alexandr; Coniglio, Marcelo; D'Ottaviano, Itala Maria Lof (eds.) 2002. Paraconsistency: The Logical Way to the Inconsistent. New York: Marcel Dekker.

Cartwright, Nancy 1983. How the Laws of Physics Lie. Oxford: Clarendon Press.

Castillo, Ana 1996. Goddess of the Americas. New York: Riverhead.

Chaitin, Gregory J. 2001. Exploring Randomness. New York: Springer.

Chiasson, Phyllis 2000. Peirce's logic of vagueness. Digital Encyclopedia of Charles S. Peirce. ${ }^{15}$

Costa, Newton C. A. da 1974. On the theory of inconsistent formal systems. Notre Dame Journal of Formal Logic 15: 497-510.

CP $=$ Peirce, Charles Sanders 1931-35. Collected Papers of Charles Sanders Peirce, vols. 1-6 [Hartshorne, C.; Weiss, P (eds.). 1931-35]; vols. 7-8. [Burks, A. W. (ed.) 1958] Cambridge: Harvard University Press.

Davidson, Donald 1984. Inquiries into Truth and Interpretation. Oxford: Clarendon Press.

Davies, Paul 1999. The Fifth Miracle: The Search for the Origin and Meaning of Life. New York: Simon and Schuster.

- 2003. Introduction: Toward an emergentist worldview. In: Gregersen, N. H. (ed.). From Complexity to Life: On the Emergence of Life and Meaning. Oxford: Oxford University Press, 3-15.

Dembski, William A. 2003. Can evolutionary algorithms generate specified complexity? In: Gregersen, N. H. (ed.). From Complexity to Life: On the Emergence of Life and Meaning. Oxford: Oxford University Press, 93-113.

Duhem, Pierre 1954. The Aim and Structure of Physical Theory. Princeton: Princeton University Press. [Trans. P. P. Wiener]

Eagleton, Terry 1996. The Illusions of Postmodernism. Oxford: Blackwell.

Elizondo, Virgil 1997. Guadalupe: Mother of the New Creation. Maryknoll: Orbis.

Engel-Tiercelin, Claudine 1992. Vagueness and the unity of C. S. Peirce's realism. Transactions of the Charles S. Peirce Society 28(1): 51-82.

Feyerabend, Paul K. 1975. Against Method. London: NLB.

Fraassen, Bas C. van 1974. The labyrinth of quantum logics. In: Cohen, R. S.; Wartofsky, M. W. (eds.) Logical and Epistemological Studies in Contemporary Physics. Dordrecht: D. Reidel, 224-254.

Gähde, Ulrich; Stegmüller, Wolfgang 1986. An argument in favor of the DuhemQuine thesis: From the structuralist point of view. In: Hahn, L. E.; Schilpp, P. A. (eds.). The Philosophy of V. W. Quine. LaSalle: Open Court, 117-136.

Gärdenfors, Peter 1994. Induction, conceptual spaces, and AI. In: Stalker, D. (ed.). Grue!, the New Riddle of Induction. LaSalle: Open Court, 117-34.

15 See http://www.digitalpeirce.org . 
Glantz, Margo 1995. La Malinche: La lengua en la mano'. In: Florescano, E. (ed.). Mitos mexicanos. México: Aguilar, 119-137.

Goldstein, Rebecca 2005. Incompleteness: The Proof and Paradox of Kurt Gödel. New York: W. W. Norton.

Goodman, Nelson 1965. Fact, Fiction and Forecast [2nd ed]. Indianapolis: Bobbs-Merrill.

- 1978. Ways of Worldmaking. Indianapolis: Hackett.

Habermas, Jürgen 1971. Knowledge and Human Interests. Boston: Beacon. [Trans. J. J. Shapiro.]

- 1979. Communication and the Evolution of Society. Boston: Beacon. [Trans. T. McCarthy]

Hausman, Carl R. 1993. Charles S. Peirce's Philosophy. Cambridge: Cambridge University Press.

Heelan, Patrick A. 1974. Quantum logic and classical logic: Their respective roles. In: Cohen, R. S.; Wartofsky, M. W. (eds.). Logical and Epistemological Studies in Contemporary Physics. Dordrecht: D. Reidel, 318-349.

Hempel, Carl 1945. Studies in the logic of confirmation. Mind 54: 1-26, 97-121.

Hesse, Mary 1969. Ramifications of "Grue". British Journal of the Philosophy of Science 20: 13-25.

Hookway, Christopher 1985. Peirce. London: Routledge and Kegan Paul.

Lafaye, Jacques 1976. Quetzalcóatl and Guadalupe: The Formation of Mexican National Consciousness. Chicago: University of Chicago Press, 1531-1813.

Lane, Robert 1999. Peirce's triadic logic revisited. Transactions of the Charles $S$. Peirce Society 35(2): 284-311.

Margolis, Joseph 1991. The Truth about Relativism. London: Basil Blackwell.

Maza, Francisco de la 1953. El guadalupanismo mexicano. México: Porrúa y Obregón.

Merrell, Floyd 1995. Semiosis in the Postmodern Age. West Lafayette: Purdue University Press.

- 1997. Peirce, Signs, and Meaning. Toronto: University of Toronto Press.

- 2000. Signs, Science, Self-Subsuming (Arti)Facts. Dresden: Thelem Press.

- 2003. Sensing Corporeally: Toward a Posthuman Understanding. Toronto: University of Toronto Press.

- 2004. Complementing Latin American Borders. West Lafayette: Purdue University Press.

- 2007. Processing Cultural Meaning. Ottawa: Legas Press.

MS = Peirce, Charles Sanders. From the unpublished manuscripts, on microfilm, Indianapolis, IUPUI.

Nadin, Mihai 1982. Consistency, completeness and the meaning of sign theories. American Journal of Semiotics 1(3): 79-98.

- 1983. The logic of vagueness and the category of synechism. In: Freeman, E. (ed.). The Relevance of Charles Peirce. LaSalle: Monist Library of Philosophy, 154-166.

Nagel, Ernest; Newman, James R. 1958. Gödel's Proof. New York: New York University Press. 
Nebel, Richard 1995. Santa María Tonantzin: Virgen de Guadalupe. México: Fondo de Cultura Económica.

Ortega y Gasset, José 1961. History as a System. New York: Norton.

Pallares, Salvador 1981. La aparición de la Virgen de Guadalupe. Servir 17: 9394.

Petrilli, Susan; Ponzio, Augusto 2005. Semiotics Unbounded: Interpretive Routes through the Open Network of Signs. Toronto: University of Toronto Press.

Poincaré, Henri 1958. Science and Method. New York: Dover.

Popper, Karl R. 1963. Conjectures and Refutations: The Growth of Scientific Knowledge. Oxford: Oxford University Press.

Priest, Graham 1991. The limits of thought — and beyond. Mind 100: 361-370.

- 1998. What is so bad about contradictions? The Journal of Philosophy 45(8): 410-426.

Priest, Graham; Routley, Richard; Norman, Jean (eds.) 1989. Paraconsistent Logic: Essays on the Inconsistent. Munich: Philosophia Verlag.

Putnam, Hilary 1983. Vagueness and alternative logic. Erkenntnis 19: 297-314.

Queiroz, João; Merrell, Floyd (eds.) 2005. Abduction: Between Subjectivity and Objectivity, special issue of Semiotica 153(1/4).

Quine, Willard V. O. 1953. From a Logical Point of View. New York: Harper and Row.

- 1960. Word and Object. Cambridge: MIT.

- 1969. Ontological Relativity and Other Essays. New York: Columbia University Press.

Rescher, Nicholas 1978. Peirce's Philosophy of Science. Notre Dame: University of Notre Dame Press.

- 2004. Pluralism: Against the Demand for Consensus. New York: Oxford University Press.

Rescher, Nicholas; Brandom, Robert 1979. The Logic of Inconsistency: A Study of Non-Standard Possible World Semantics and Ontology. Totowa: Rowman and Littlefield.

Rodríguez, Jeannette 1994. Our Lady of Guadalupe: Faith and Empowerment among Mexican-American Women. Austin: University of Texas Press.

Rorty, Richard 1979. Philosophy and the Mirror of Nature. Princeton: Princeton University Press.

- 1982. Consequences of Pragmatism. Minneapolis. University of Minnesota Press.

- 1991. Inquiry as recontextualization. In: Hiley, R.; Bohman, J. F.; Schusterman, R. (eds.). The Interpretive Turn: Philosophy, Science, Culture, D. Ithaca: Cornell University Press, 59-80.

Rosenthal, Sandra B. 1994. Charles Peirce's Pragmatic Pluralism. Albany: State University of New York Press.

- 2004. Peirce's pragmatic account of perception: Issues and implications. In: Misak, C. (ed.). The Cambridge Companion to Peirce. Cambridge: Cambridge University Press, 193-213.

Roth, Paul A. 1987. Meaning and Method in the Social Sciences: A Case for Methodological Pluralism. Ithaca: Cornell University Press. 
Russell, Bertrand 1923. Vagueness. Australian Journal of Philosophy 1: 88-91. Sacks, Mark 1989. The World We Found: The Limits of Ontological Talk. LaSalle: Open Court.

Sahlins, Marshall 1978. Culture and Practical Reason. Chicago: University of Chicago Press.

Shusterman, Richard 1992. Pragmatist Aesthetics: Living Beauty, Rethinking Art. Oxford: Blackwell.

- 1997. Practicing Philosophy: Pragmatism and the Philosophical Life. London: Routledge.

Siller Acuña; Glodomiro L. 1989. Para comprender el mensaje de María de Guadalupe. Buenos Aires: Editorial Guadalupe.

Skagestad, Peter 1981. The Road to Inquiry: Charles Peirce's Pragmatic Realism. New York: Columbia University Press.

Vuillemin, Jules 1986. On Duhem's and Quine's thesis. In: Hahn, L. E.; Schilpp, P. A. (eds.). The Philosophy of W. V. Quine. LaSalle: Open Court, 595-618.

Wittgenstein, Ludwig 1953. Philosophical Investigations. New York: Macmillan. [Trans. G. E. M. Anscombe.]

Zadeh, Lofti 1965. Fuzzy sets. Information and Control 8: 338-353.

- 1975. Fuzzy Logic and approximate reasoning (In memory of Grigore Moisil). Synthese 30: 407-428.

\section{К вопросу о плюралистическом и интерреляционном понятии семиозиса}

Всю сложность любой достаточно развитой знаковой системы можно охватить с помощью: 1) Пирсовской «логики неопределенности», 2) его категорий, 3) понятий сверх- и недодетерминированность, неясность и всеобщность, противоречивость и неукомплектованность, 4) опровержения принципов классической аристотелевской логики. Благодаря сложности знаковых систем существует семиотическая неопределенность, которая с одной стороны предполагает ограниченность знаков, но в то же время позволяет и семиотическую свободу, которая становится причиной размножения знаков, результатом которого в свою очередь будет плюралистический интерреляционный семиозис. Это размножение знаков обязано своим непрекращающимся текучим изменением тому факту, что правила «непротиворечивости» и «исключенного третьего» классической логики неприменимы к ним ввиду неясности и всеобщности, содержащихся во всех знаках. Все ограничения и свобода при создании и выявлении знаков объяснимы в рамках «индуктивного парадокса» Хемпеля и «новой загадки индукции» Гудмена. В качестве конкретного примера в статье с помощью методик Хемпеля и Гудмена 
анализируется противостояние картины мира испанцев, в центре которой находится гваделупская Дева, миру ацтеков (в центре которой стоит бог Тонанцин). Пример иллюстрирует многозначную, неясную и сложную природу межкультурных знаковых систем, в дальнейшем приводящие к плюрализму. Фактически, исходя из «ограничивающих/лимитирующих теорем» Гёделя, Тюринга и Чейтина невозможно отрицать плюрализм, прежде всего из-за противоречивости и неукомплектованности сложных структур. Одной из возможных моделей, описывающих плюрализм, могло бы быть стремящееся к релятивизму контекстуализированное новшество. Эта форма плюрализма охватывает сверхдетерминированность (что характерно в общих чертах пирсовской Первичности) и недодетерминированность (что в общих чертах характерно для пирсовской Третичности), выдвигая социальный контекст, через который становится возможным объяснить все локальные контексты. Нужно иметь в виду, что сумма всех локальных контекстов никогда не достигает уровня глобального контекста, так как целостность глобального контекста никогда невозможно охватить полностью по причине неизбежной конечности и фаллибилизма нас как субъектов. Тем не менее мы обычно способны справится с процессуальным плюрализмом в рамках игры семиозиса.

\section{Pluralistliku ja suhestusliku semioosi mõiste suunas}

Ükskõik millise rikkaliku märgisüsteemi kogu keerukus on hõlmatav järgmiste elementidega: Peirce'i 'ähmasuse loogika', tema kategooriate, mõistete ülemääratletus ja alamääratletus, ähmasus ja üldisus, vastukäivus ja poolikus analüüs ning klassikalise aristotelliku loogikapõhimõtete kummutamine. Tingitud märgisüsteemide keerukusest, eksisteerib teatud semiootiline määramatus, mis ühelt poolt eeldab märkide piiritletust, kuid võimaldab samaaegselt semiootilist vabadust, mis põhjustab märkide vohamist, mille tulemuseks on omakorda pluralistlik suhestuslik semioos. Märkide vohamise igavene voolav muutumine on võimalik seepärast, et klassikalise loogika 'mittevasturääkivuse' ja 'välistatud kolmanda' reegleid ei ole neile võimalik rakendada kõikides märkides sisalduva ähmasuse ja üldisuse tõttu. Kõik märgiloomise ja märgistatud saamise piirangud ja vabadus on selgitatav Hempeli 'induktiivsusparadoksi' ja Goodmani 'uue induktsioonimõistatuse' raames. Konkreetse kultuurinäitena analüüsitakse käesolevas artiklis Hempeli ja Goodmani 
metoodika järgi hispaanlaste maailmapilti, mille keskmes oli Guadalupe Neitsi, vastanduses asteekide maailmaga, mille keskmes oli jumal Tonantzín, illustreerimaks pluralismi aluseks olevate kultuuridevaheliste märgisüsteemide mitmetimõistetavat, ähmast ja keerukat loomust. Õigupoolest on Gödeli, Turingi ja Chaitini 'piiritlevatest teoreemidest' lähtudes pluralismi võimatu eitada, seda eelkõige keerukate struktuuride vastukäivuse ja poolikuse tõttu. Üheks mudeliks pluralismi käsitlemisel võiks olla relativismi poole püüdlev kontekstualiseeritud uudsus. See pluralismi vorm hõlmab ülemääratletust (mis on üldjoontes iseloomulik Peirce'i Esmasusele) ja alamääratletust (mis on üldjoontes iseloomulik Peirce'i Kolmasusele), tuues esile globaalse konteksti, mille kaudu on võimalik seletada kõiki lokaalseid kontekste. Tuleb silmas pidada, et kõikide lokaalsete kontekstide summa ei küüni kunagi taolise globaalse konteksti tasemele, kuivõrd globaalse konteksti terviklikkust ei ole meie kui subjektide lõplikkuse ja ekslikkuse tõttu iialgi võimalik täielikult haarata. Siiski oleme semioosi mänguruumis enamasti võimelised toime tulema protsessuaalse pluralismiga. 